Research Article

\title{
Ethanolic Fruit Extract of Emblica officinalis Suppresses Neuroinflammation in Microglia and Promotes Neurite Outgrowth in Neuro2a Cells
}

\author{
Sataporn Phochantachinda (D), ${ }^{1}$ Duangthip Chatchaisak, ${ }^{2}$ Piya Temviriyanukul (D), \\ Anchana Chansawang, ${ }^{4}$ Pornsiri Pitchakarn, ${ }^{5}$ and Boonrat Chantong ${ }^{6}{ }^{6}$ \\ ${ }^{1}$ Prasu-Arthorn Animal Hospital, Faculty of Veterinary Science, Mahidol University, Salaya, \\ Phutthamonthon, Nakhon Pathom 73170, Thailand \\ ${ }^{2}$ Department of Clinical Sciences and Public Health, Faculty of Veterinary Science, Mahidol University, Salaya, \\ Phutthamonthon, Nakhon Pathom 73170, Thailand \\ ${ }^{3}$ Institute of Nutrition, Mahidol University, Salaya, Phutthamonthon, Nakhon Pathom 73170, Thailand \\ ${ }^{4}$ The Center for Veterinary Diagnosis, Faculty of Veterinary Science, Mahidol University, Salaya, \\ Phutthamonthon, Nakhon Pathom 73170, Thailand \\ ${ }^{5}$ Department of Biochemistry, Faculty of Medicine, Chiang Mai University, Chiang Mai 50200, Thailand \\ ${ }^{6}$ Department of Pre-Clinical and Applied Animal Science, Faculty of Veterinary Science, Mahidol University, Salaya, \\ Phutthamonthon, Nakhon Pathom 73170, Thailand
}

Correspondence should be addressed to Boonrat Chantong; boonrat.cha@mahidol.ac.th

Received 28 June 2021; Revised 20 August 2021; Accepted 27 August 2021; Published 8 September 2021

Academic Editor: Md. Sahab Uddin

Copyright (c) 2021 Sataporn Phochantachinda et al. This is an open access article distributed under the Creative Commons Attribution License, which permits unrestricted use, distribution, and reproduction in any medium, provided the original work is properly cited.

\begin{abstract}
Inhibiting neuroinflammation and modulating neurite outgrowth could be a promising strategy to prevent neurological disorders. Emblica officinalis (EO) may be a potent agent against them. Although EO extract reportedly has anti-inflammatory properties in macrophages, there is limited knowledge about its neuroprotective activity by suppressing microglia-mediated proinflammatory cytokine production and inducing neurite outgrowth. The present study aimed to elucidate the effect of EO fruit extract on the lipopolysaccharide- (LPS-) induced neuroinflammation using microglial (BV2) and neuroblastoma (Neuro2a) cells. The results demonstrated that, in LPS-treated BV2 cells, EO fruit extract reduced nitric oxide, interleukin-6, and tumor necrotic factor- $\alpha$ production. It also enhanced the neurite length of Neuro2a cells, which was linked to the upregulation of TuJ1 and MAP2 expressions. In conclusion, these findings indicate that the ethanolic extract of EO fruits has promising neuroprotective potential to exhibit antineuroinflammation activity and accelerative effect on neurite outgrowth in vitro. Therefore, EO fruit extract can be considered a novel herbal medicine candidate for managing neuroinflammatory diseases.
\end{abstract}

\section{Introduction}

Neuroinflammation is the primary cause of most neurological diseases [1]. It is involved in major neurodegenerative disorders such as Alzheimer's disease (AD) and Parkinson's disease (PD) $[2,3]$. Microglia are represented by resident immune cells in the defense system against inflammation in the brain [4]. Activated microglial and neuritic abnormalities constitute a significant $\mathrm{AD}$ and $\mathrm{PD}$ pathology $[5,6]$.
Neuroinflammation activates microglial cells to release proinflammatory cytokines and toxic factors, such as superoxide radicals, nitric oxide (NO), interleukin-6 (IL-6), and tumor necrotic factor- $\alpha$ (TNF- $\alpha$ ), that damage neurons $[7,8]$.

In this study, lipopolysaccharide (LPS) application, as a potent stimulus of the microglial innate immune response [5], induced neuroinflammation associated with neurodegeneration, especially in the AD model $[9,10]$. LPS can 
activate microglia to increase the production of inflammatory cytokines through both toll-like receptor 4 (TLR4) and mitogen-activated protein kinase (MAPK) pathways [11] that exacerbate the pathology of neurodegenerative processes [12]. The MAPK pathway is employed in cellular processes such as proliferation, differentiation, apoptosis, cell survival, cell motility, metabolism, stress response, and inflammation [13]. Activated microglia release proinflammatory cytokines (NO, IL-6, and TNF- $\alpha$ ), inducing cognitive impairment and neuroinflammation $[4,5,14,15]$.

A previous study reported that interleukin-6 (IL-6) decreased the differentiation of neural stem/progenitor cells into neurons, promoted gliogenesis, oligodendrogliogenesis, and astrogliogenesis, and reduced neurogenesis via the MAPK/CREB pathway [16]. Moreover, inflammation-mediated neurodegeneration involves inducible nitric oxide synthase (iNOS) overexpression, causing toxicity to neurons by overproducing $\mathrm{NO}$ in activated microglia [17]. The MAPK pathway played a role in regulating several signaling molecules, including NO, IL-6, and TNF- $\alpha[18,19]$. Pieces of evidence indicate that suppressing the MAPK pathway can reduce neuroinflammation or neurodegenerative disorders [20-22]. Therefore, this study aimed to investigate neuroinflammation inhibition via the MAPK pathway suppression that would reduce inflammatory-related molecule production.

Differentiation of neuronal cells is an important key factor for the prevention of neurodegenerative diseases. Numerous specific neuronal markers are expressed during neuronal differentiation. Beta-III tubulin (TuJ1) is a marker for early differentiated neurons related to the cellular movement during mitosis [23]. Microtubule-associated protein-2 (MAP2) is a marker for mature neurons [24], which binds and stabilizes microtubules by altering their disassembly duration [25]. Many studies use TuJ1 and MAP2 as neuronal markers to investigate protein or mRNA expression $[25,26]$. Both $\mathrm{TuJ} 1$ and MAP2 reportedly modulate the growth and stabilization of microtubules in neurites of Neuro2a cells [27]. Enhancing neurite outgrowth represented by their increased length and branching is essential for treating neurodegenerative diseases [28, 29]. Inducing neuronal differentiation was intended to be investigated in this study by measuring TuJ1 and MAP2 expression.

Using phytochemicals as nutraceuticals has expanded substantially. Natural products, used as nutraceuticals to increase pharmacological response and minimize some adverse effects, are extensively considered. Many traditional Ayurvedic medicinal plants such as Bacopa monnieri and Mucuna pruriens have been studied for either neuroprotective or anti-inflammatory properties in neuronal cells $[30,31]$. The present study was focused on antineuroinflammation and neuroprotective effects of Emblica officinalis (EO) fruit ethanol extract. This species is found in many regions of Southeast Asia [32] and is widely accepted in Thailand as a traditional medicinal herb [33, 34]. EO crude extract contains various bioactive compounds, such as gallic acid (GA), ellagic acid (EA), ascorbic acid, mucic acid, tannin, quercetin, and rutin [35-37], which exerted protective activities, including anti-inflammatory, antitumor, antioxidation, and immunomodulatory effects, to prevent central nervous system diseases [34, 38, 39]. Previous studies suggested that both GA and EA might cross the blood-brain barrier. The present study, therefore, was concentrated on these two compounds. GA administration reportedly prevented oxidative damage and neuroinflammation during brain injury induced by LPS and ketamine administration in rats [40-42]. GA also protected memory and reduced long-term potentiation impairment caused by traumatic brain injury by reducing both brain lipid peroxidation and cerebral proinflammatory cytokines [43]. Furthermore, EA is known to attenuate anxiety, depression, locomotion behavior, brain edema, and inflammation in rats with cerebral ischemia/reperfusion by decreasing brain tissue inflammation [44]. EA showed a protective effect against brain injury induced by LPS and carbon tetrachloride in rats by modulating the Nrf-2, NF$\kappa \mathrm{B}$, and apoptotic pathways $[45,46]$. Although EO's antiinflammatory properties were previously investigated, the molecular basis behind these anti-inflammatory effects in the neuronal system has not yet been scrutinized. To the best of our knowledge, no studies have ascertained the effect of EO crude fruit extract on neuroinflammation using microglia and neurite outgrowth with neuroblastoma cells as model systems. Therefore, we intended to examine the role of EO fruit extract in regulating neuroinflammation and its neuroprotective effects in a cellular system made of microglia and neurons.

\section{Materials and Methods}

2.1. Reagents. A $2 \times \mathrm{qPCRBIO}$ SyGreen 1 -Step Lo-ROX kit was obtained from PCR Biosystems (Wayne, Pennsylvania, USA). We purchased the Bradford solution, blottinggrade blocker (nonfat dry milk), and polyvinylidene fluoride (PVDF) membrane from Bio-Rad (Benicia, CA, USA). All-trans retinoic acid, EA, GA, and LPS (from Escherichia coli O111:B4) were acquired from SigmaAldrich (St. Louis, MO, USA). Antibodies specific to $\beta$-actin (cat no. 4970S), TuJ1 (cat no. 5568S), ERK1/2, (cat no.4695S), pERK1/2 (cat no. 4376S), JNK (cat no. 9252S), or pJNK (cat no. 4671S) came from Cell Signaling Technology (Danvers, MA, USA). We obtained cytosine arabinoside hydrochloride, the IL- 6 quantitative sandwich enzyme-linked immunosorbent assay (ELISA) kit, radioimmunoprecipitation assay (RIPA) buffer, and XTT solution salt from Abcam (Cambridge, MA, USA). The TNF- $\alpha$ sandwich ELISA kit was purchased from BioLegend (San Diego, CA, USA). Ethanol and methanol were purchased from Merck (Darmstadt, Germany). Fetal bovine serum (FBS), fungizone, minimal essential medium (MEM), penicillin, Roswell Park Memorial Institute (RPMI) medium 1640, and streptomycin were acquired from GIBCO (Waltham, MD, USA). The Griess reagent and tetramethylbenzidine (TMB)-stabilized substrate for horseradish peroxidase were purchased from Promega (Madison, WI, USA). Tri-RNA Reagent was purchased from Favorgen (Kaohsiung, Taiwan). 
2.2. EO Crude Fruit Extract Preparation. We purchased Emblica officinalis Gaertn. (EO) fruits from an orchard in Nakhon Pathom Province. The fruits were washed with tap water and rinsed with distilled water to remove potential contaminants. Then, clean fruits were chopped and dried in an oven at $60^{\circ} \mathrm{C}$. We ground dried fruits into smaller parts for extraction. Next, we macerated EO fruit powder in $70 \%$ ethanol (at $1: 10 \mathrm{w} / \mathrm{v}$ ) at room temperature for six days (the powder was filtered and macerated in fresh $70 \%$ ethanol every two days). Ethanol was subsequently removed using a rotary evaporator (Heidolph, Wood Dale, IL, USA) at $40^{\circ} \mathrm{C}$. We obtained EO crude fruit extract using a dry freezing machine (Modulyo, Waltham, MA, USA). Finally, we prepared stock solutions by dissolving the extract in dimethyl sulfoxide and stored at $-80^{\circ} \mathrm{C}$ until further use.

\subsection{Quantification of Compounds Present in EO Crude Fruit} Extract by High-Performance Liquid Chromatography (HPLC). We prepared EO crude fruit extract at the concentration of $1 \mathrm{mg} / \mathrm{mL}$. GA and EA, used as standard compounds, were prepared at five concentrations $(25,50$, $100,200$, and $400 \mu \mathrm{g} / \mathrm{mL})$. We filtered each solution by syringe through a nylon filter with a pore size of $0.45 \mu \mathrm{m}$ and subsequently subjected to HPLC analysis (Shimadzu HighPerformance LC 10 AP; Shimadzu Scientific, MA, USA). Samples were eluted through an ACE Generix $5 \mu \mathrm{m} \mathrm{C18}$ column $(4.6 \mathrm{~mm} \times 250 \mathrm{~mm})$ (Advanced Chromatography Technologies, Scotland, UK) using mobile phase: $0.1 \%$ acetic acid (A) and methanol (B) with a flow rate of $1.5 \mathrm{~mL} / \mathrm{min}$. The gradient program was as follows-0-15 min: $5 \% \mathrm{~B}$; $15-40$ min: $80 \%$ B; $40-42 \min : 5 \%$ B; $42-50 \min : 5 \% \mathrm{~B}$. The injection volume of each sample was $10 \mu \mathrm{L}$. A photodiode array detector detected eluted compounds, and the UV detection wavelength was set to $278 \mathrm{~nm}$.

\subsection{Cell Culture System}

2.4.1. BV2 Cell Culture. BV2 cells, a mouse microglial cell line, were purchased from Interlab Cell Line Collection (ATL033001). The cells were cultured at $37^{\circ} \mathrm{C}$ in RPMI medium 1640, containing $10 \%(\mathrm{v} / \mathrm{v})$ heat-inactivated FBS, $100 \mathrm{IU} / \mathrm{mL}$ penicillin, $100 \mu \mathrm{g} / \mathrm{mL}$ streptomycin, $0.25 \mathrm{mg} / \mathrm{mL}$ sodium bicarbonate, and $2.5 \mu \mathrm{g} / \mathrm{mL}$ fungizone, in a humidified incubator containing $5 \% \mathrm{CO}_{2}$. BV2 cells were seeded at a density of $1.5 \times 10^{3}$ cells $/ \mathrm{cm}^{2}$ in $75 \mathrm{~cm}^{2}$ flasks in RPMI medium with $10 \%$ FBS and then passed at approximately $80 \%$ confluence.

2.4.2. Neuro2a Cell Culture and Differentiation. Neuro2a cells, a mouse neuroblastoma cell line, were purchased from ATCC (CCL-131TM). They were cultured at $37^{\circ} \mathrm{C}$ in MEM, supplemented with $10 \% \mathrm{FBS}, 100 \mathrm{IU} / \mathrm{mL}$ penicillin, $100 \mu \mathrm{g} /$ $\mathrm{mL}$ streptomycin, $0.25 \mathrm{mg} / \mathrm{mL}$ sodium bicarbonate, and $2.5 \mu \mathrm{g} / \mathrm{mL}$ fungizone, in a humidified incubator containing $5 \% \mathrm{CO}_{2}$. Neuro2a cells were seeded at a density of $1.5 \times 10^{3}$ cells $/ \mathrm{cm}^{2}$ in a $75 \mathrm{~cm}^{2}$ flask in MEM medium with $10 \% \mathrm{FBS}$ and then passed at approximately $80 \%$ confluence.
After that, Neuro2a cells had to differentiate to express characteristics of neuron cells by retinoic acid before conducting further tests [47-49]. It was accomplished by seeding cells in DMEM with 2\% FBS and changing medium every two days until six days passed. From day 0 to day 2, we used DMEM with 2\% FBS and all-trans retinoic acid $(10 \mu \mathrm{M})$. After that, we used DMEM supplemented with $2 \%$ FBS, all-trans retinoic acid $(10 \mu \mathrm{M})$, and cytosine arabinoside hydrochloride $(0.5 \mu \mathrm{M} / \mathrm{mL})$ from day 2 to day 4 . After four days, the medium was replaced by DMEM containing $2 \%$ FBS and retinoic acid $(10 \mu \mathrm{M})$ until the end of the $6^{\text {th }}$ day.

2.5. Investigation of Toxicity of EO Fruit Extract and LPS to BV2 and Neuro2a Cells by XTT Reduction Assay. Neuro2a cells or BV2 cells were seeded in 96-well culture plates at a density of $1 \times 10^{4}$ cells/well and incubated for $24 \mathrm{~h}$ in a $\mathrm{CO}_{2}$ incubator. The medium was subsequently replaced either by EO crude fruit extract resuspended in a medium $(0.125-1 \mu \mathrm{g} / \mathrm{mL})$ or by LPS $(1 \mu \mathrm{g} / \mathrm{mL})$ and further incubated for $24 \mathrm{~h}$. After that, we removed the medium and added XTT solution to the cells. We performed further incubation at $37^{\circ} \mathrm{C}$ for $2 \mathrm{~h}$. Finally, the absorbance was read at $450 \mathrm{~nm}$ using a microplate reader (BioTek, Winooski, VT, USA). We used untreated cells as a negative control. Data were expressed as a percentage compared to control.

\subsection{Investigation of the Anti-Inflammatory Effect of EO Crude Fruit Extract on LPS-Induced Inflammation of BV2 and Neuro2a Cells}

2.6.1. Cell Treatment. We seeded either Neuro2a or BV2 cells in 6-well culture plates and allowed to adhere to the plate overnight in a $\mathrm{CO}_{2}$ incubator. We replaced the medium with EO $(1 \mu \mathrm{g} / \mathrm{mL})$ or GA $(31 \mathrm{ng} / \mathrm{mL})$ or EA $(15 \mathrm{ng} / \mathrm{mL})$ in the presence of LPS $(1 \mu \mathrm{g} / \mathrm{mL})$ and incubated for $24 \mathrm{~h}$. GA and EA were used as positive controls.

2.6.2. IL-6 and TNF- $\alpha$ Measurement by ELISA. After the treatment, the culture medium was collected and centrifuged at $2000 \times g$ for $10 \mathrm{~min}$ at $4^{\circ} \mathrm{C}$. The resulting supernatant was subjected to ELISA. A quantitative sandwich ELISA kits was used to measure IL- 6 and TNF- $\alpha$ in samples. The measurements were performed according to the manufacturer's recommendations. Concentrations of IL- 6 and TNF- $\alpha$ were calculated from standards, ranging from 15 to $500 \mathrm{pg} / \mathrm{mL}$.

2.6.3. Nitric Oxide (NO) Measurement Using Griess Reagent. After the treatment, culture media of either Neuro2a or BV2 cells were collected and centrifuged at $2000 \times g$ for $10 \mathrm{~min}$ at $4^{\circ} \mathrm{C}$. Nitrite concentration was assessed in the resulting supernatant using the Griess reagent, according to the manufacturer's recommendations. Briefly, $50 \mu \mathrm{L}$ of each culture medium was mixed with the same volume of the reagent. The nitrite level was determined using a microplate reader at the wavelength of $550 \mathrm{~nm}$. Nitrite concentrations were calculated in comparison to a standard curve of sodium nitrite. 
2.6.4. Neurite Measurement and Morphology Determination. We treated Neuro2a cells with various GA or EA extract concentrations for $24 \mathrm{~h}$. We observed the cells and photographed them under an inverted microscope (ECLIPSE Ts2; Nikon, NY, USA) with phase-contrast objectives. The length of neurites was measured using MicroCapture software v. 6.9.10. We conducted each experiment in triplicate.

For morphology imaging, we performed cell treatments in an imaging dish (TomoDish; Tomocube Inc., Daejeon, South Korea). Then, we directly observed the cells using an HT instrument (HT-2; Tomocube Inc., Daejeon, South Korea).

2.6.5. Western Blot Analysis. After $24 \mathrm{~h}$ of treatment, we collected either Neuro2a or BV2 cells with a RIPA buffer. We measured protein concentration by Bradford assay. Each protein sample $(10 \mu \mathrm{g})$ was separated using $10 \%$ sodium dodecyl sulfate-polyacrylamide (SDS) gel, transferred to a PVDF membrane, and blocked with 5\% (w/v) nonfat milk in Tris-buffered saline with $0.1 \%$ Tween 20 (TBST) at room temperature for an hour. The membrane was incubated overnight at $4^{\circ} \mathrm{C}$ with primary rabbit monoclonal antibodies against $\beta$-actin, TuJ1, ERK1/2, pERK1/2, JNK, and pJNK at the dilution of $1: 1000$. The membrane was further incubated at room temperature with secondary antibodies at $1: 1000$ dilution. The TMB substrate solution detected bands, and we analyzed their density by ImageJ software.

2.6.6. RNA Extraction and Analysis by Reverse TranscriptionQuantitative Polymerase Chain Reaction (RT-qPCR). After the treatment, either Neuro2a or BV2 cells were collected and dissolved in Tri-RNA Reagent. Total RNA was extracted according to the manufacturer's instructions. The RT-qPCR reaction mixture contained $5 \mu \mathrm{L}$ of $2 \times$ qPCRBIO SyGreen 1-Step Lo-ROX, $0.5 \mu \mathrm{L}$ of $20 \times$ RTase GO, $0.4 \mu \mathrm{L}$ of each primer $(10 \mu \mathrm{M}), 100 \mathrm{ng}$ of RNA template, and $6.3 \mu \mathrm{L}$ of RNase-free water. PCRs were conducted in qTOWER3 RealTime PCR (qPCR) Systems (Analytik Jena, Langewiesen, Germany). The cycle conditions included a reverse transcription step at $45^{\circ} \mathrm{C}$ for $10 \mathrm{~min}$, initial polymerase activation step at $95^{\circ} \mathrm{C}$ for $2 \mathrm{~min}$, and denaturation step of 40 cycles at $95^{\circ} \mathrm{C}$ for $5 \mathrm{~s}$ followed by a step of $60^{\circ} \mathrm{C}$ for $30 \mathrm{~s}$. GAPDH was used as an internal control for normalization. Table 1 presents the primer sequences.

2.7. Statistical Analysis. We performed statistical analysis using descriptive statistical procedures by GraphPad Prism v. 5 software. Values are presented as means \pm SD from at least three independent experiments. Statistical analysis was performed using one-way ANOVA followed by Tukey's test. A probability value of 0.05 or less was considered to be statistically significant.

\section{Results}

3.1. GA and EA Contents of EO Crude Fruit Extract. We obtained GA and EA contents from HPLC chromatograms. The maximum absorbance wavelength and retention time
TABle 1: Primer sequences of $\beta$-actin, TuJ1, MAP2, GAPDH, iNOS, and TNF- $\alpha$.

\begin{tabular}{lc}
\hline Gene name & Forward/reverse primer sequence \\
\hline \multirow{2}{*}{ TuJ1 } & (F) $5^{\prime}$-ACCCCGTGGGCTCAAAAT-3' \\
\hline \multirow{2}{*}{ MAP2 } & (R) $5^{\prime}$-CCGGAACATGGCTGTGAACT-3' \\
\hline \multirow{2}{*}{ GAPDH } & (F) $5^{\prime \prime}$-CCTGGTGCCCAGTGAGAAGA-3' $5^{\prime \prime}$-GTCCGGCAGTGGTTGGTTAA-3' \\
\hline \multirow{2}{*}{ iNOS } & (F) $5^{\prime}$-CTCGTGGAGTCTACTACTGGTGT-3' \\
& (R) $5^{\prime}$-GTCATCATACTTGGCAGGTT-3' \\
\hline
\end{tabular}

for GA and EA were $254 \mathrm{~nm}$ at $37 \mathrm{~min}$ and $278 \mathrm{~nm}$ at $8 \mathrm{~min}$, respectively (Figure 1). EO crude fruit extract contained $31.15 \mathrm{mg} / \mathrm{g}$ dry weight GA and $14.99 \mathrm{mg} / \mathrm{g}$ dry weight EA.

3.2. Cytotoxicity of EO Crude Fruit Extract and LPS to BV2 and Neuro2a Cells. We used murine BV2 cells and neuroblastoma Neuro2a cells as representative for neurons and microglia cells. BV2 and differentiated Neuro2a cells were exposed to EO crude fruit extract at the concentrations of $0.125,0.25,0.5$, and $1 \mu \mathrm{g} / \mathrm{mL}$ or LPS at $1 \mu \mathrm{g} / \mathrm{mL}$. After exposure, we determined cytotoxicity by the XTT reduction assay. None of the EO treatments showed decreased cellular viability after $48 \mathrm{~h}$ of exposure (Figure 2). However, $1 \mu \mathrm{g} / \mathrm{mL}$ LPS treatment for $48 \mathrm{~h}$ was slightly toxic to BV2 cells as the \% XTT reduction was lower than $80 \%$ (79.19\%) (Figure 2(a)). Therefore, a suitable exposure time and a subtoxic concentration of LPS for the further experiments were estimated to be $24 \mathrm{~h}$ and $1 \mu \mathrm{g} / \mathrm{mL}$, respectively.

3.3. Effect of EO Crude Fruit Extract on LPS-Induced IL-6 and TNF- $\alpha$ Production in BV2 and Differentiated Neuro2a Cells. We used ELISA to evaluate the medium in which the LPSinduced BV2 and Neuro2a cells were grown and inflammatory cytokines' levels to examine the effects of EO crude fruit extract on LPS-stimulated IL- 6 and TNF- $\alpha$ production. Figure 3 (a) shows that BV2 cells treated with $1 \mu \mathrm{g} / \mathrm{mL}$ LPS showed significantly increased IL-6 production compared with those in the control group. A co-treatment with EO crude fruit extract at the concentration of $1 \mu \mathrm{g} / \mathrm{mL}$ for $24 \mathrm{~h}$ significantly decreased the IL-6 production in a dose-dependent manner $(p<0.01)$. Moreover, differentiated Neuro2a cells could secrete IL-6 without LPS-induced inflammation. This result implicates that LPS could not induce IL-6 production in differentiated Neuro2a cells. Figure 3(b) shows that EO crude fruit extract at $1 \mu \mathrm{g} / \mathrm{mL}$ significantly decreased the baseline of IL- 6 production in differentiated Neuro2a cells $(p<0.01)$. Consistently, BV2 cells treated with $1 \mu \mathrm{g} / \mathrm{mL}$ LPS showed significantly increased TNF- $\alpha$ production compared with those in the control group. EO crude fruit extract at the concentrations of 0.5 and $1 \mu \mathrm{g} / \mathrm{mL}$ significantly decreased production in the LPS-activated BV2 cells $(p<0.01$ ) (Figure 3(c)). Furthermore, equivalent concentrations of GA and EA strongly reduced IL- 6 and TNF- $\alpha$ production in BV2 and reduced the 


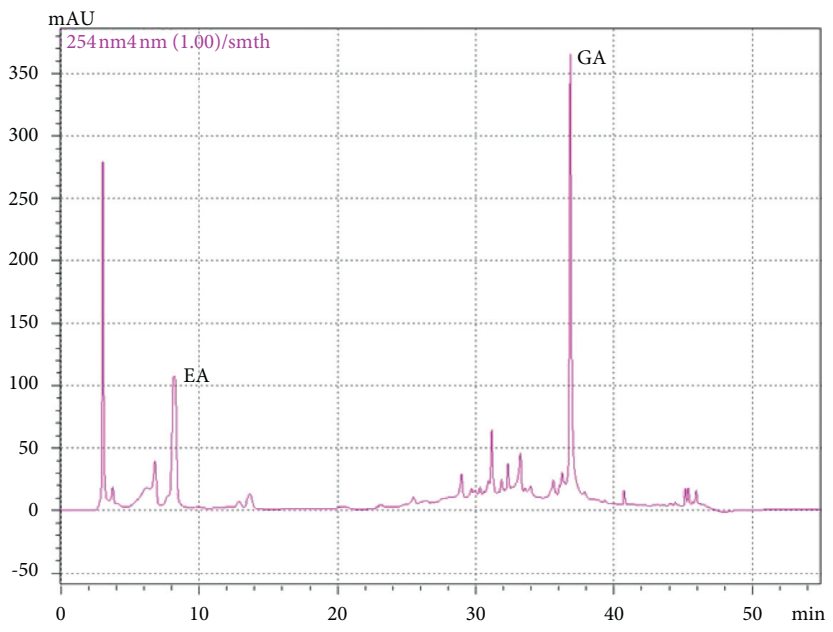

FIgURE 1: HPLC chromatogram of EO crude fruit extract. EA = ellagic acid, GA = gallic acid.

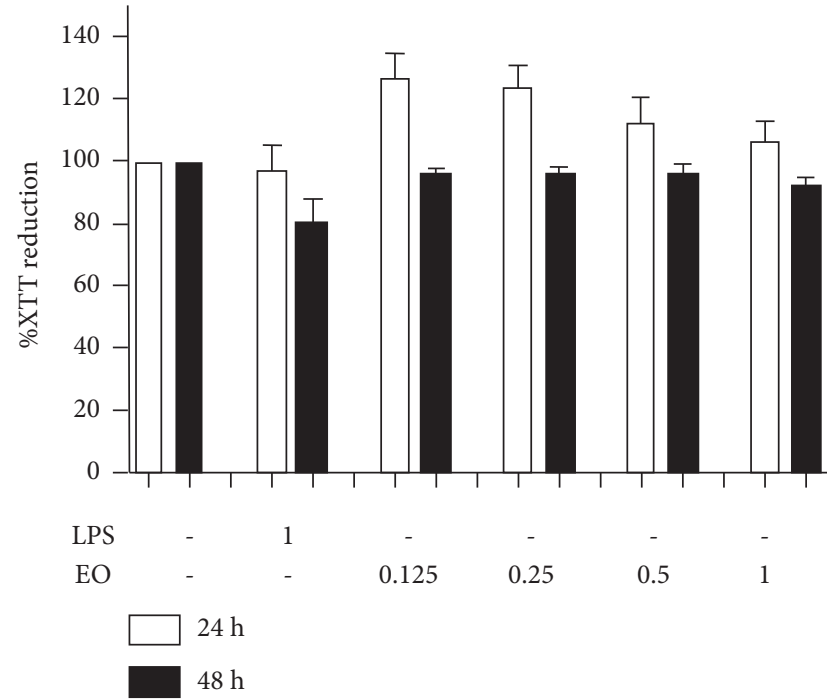

(a)

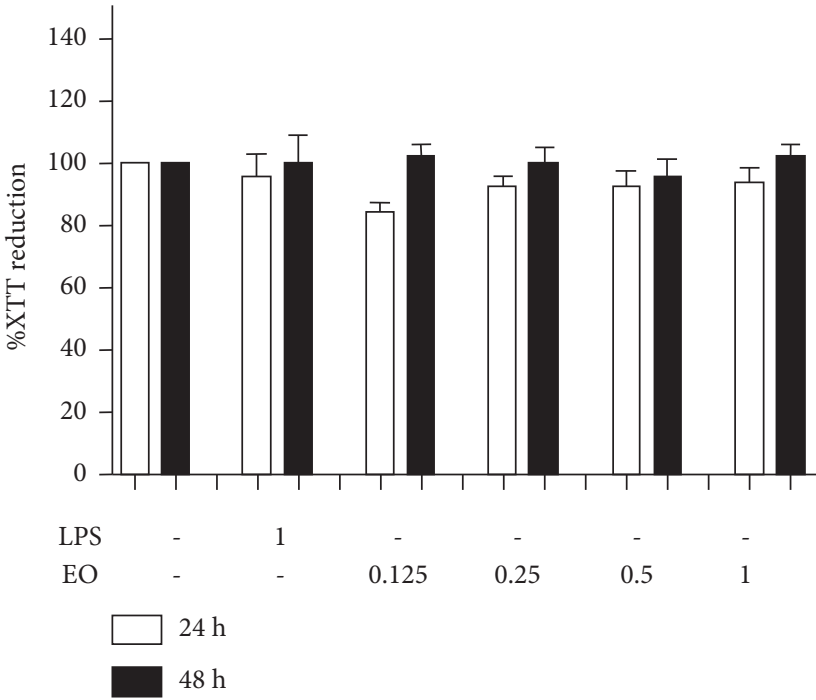

(b)

FIGURE 2: Cell viability after exposure to different EO crude fruit extract concentrations or LPS, determined by the XTT reduction assay. We treated the cells for $24 \mathrm{~h}$ or $48 \mathrm{~h}$ with varying concentrates of EO crude fruit extract $(0.125,0.25,0.5$, or $1 \mu \mathrm{g} / \mathrm{mL})$ or LPS $(1 \mu \mathrm{g} / \mathrm{mL})$ before detecting cellular viability. The results are presented as mean \pm SD. (a) BV2 cells and (b) differentiated Neuro2a cells.

IL-6 level in differentiated Neuro2a cells. However, LPS was unable to induce TNF- $\alpha$ release in differentiated Neuro2a cells.

\subsection{Effect of EO Crude Fruit Extract on LPS-Induced NO} Production and iNOS $m R N A$ Expression in BV2 and Differentiated Neuro2a Cells. To investigate the anti-inflammatory effect of EO crude fruit extract, we used LPS to stimulate NO production in BV 2 cells and then measured its content using the Griess assay. The results in Figure 4(a) and 4(b) shows that EO crude fruit extract at the concentrations of 0.5 and $1 \mu \mathrm{g} / \mathrm{mL}$ significantly decreased NO production in the LPSactivated BV2 cells in a dose-dependent manner $(p<0.01)$, but not in differentiated Neuro2a cells. In addition, the application of GA and EA at the concentration found in EO crude fruit extract $(1 \mu \mathrm{g} / \mathrm{mL})$ successfully alleviated NO production in BV2 cells. Furthermore, we examined the effect of EO crude fruit extract at the concentrations of 0.5 or $1 \mu \mathrm{g} / \mathrm{mL}$ on iNOS mRNA expression in BV2 cells. EO crude fruit extract tended to decrease the iNOS mRNA expression level by $44.67 \%$ and $54.61 \%$, compared with the LPS-treated group. Nevertheless, the effect of EO crude fruit extract on iNOS mRNA expression did not reach statistical significance (Figure 4(c)).

3.5. Effect of EO Crude Fruit Extract on LPS-Induced Inflammation in BV2 Cells via the ERK and JNK Pathways. Western blot analysis showed the expression levels of both pERK/ERK and pJNK/JNK increased in LPS-inflamed BV2 cells. However, EO crude fruit extract at the 


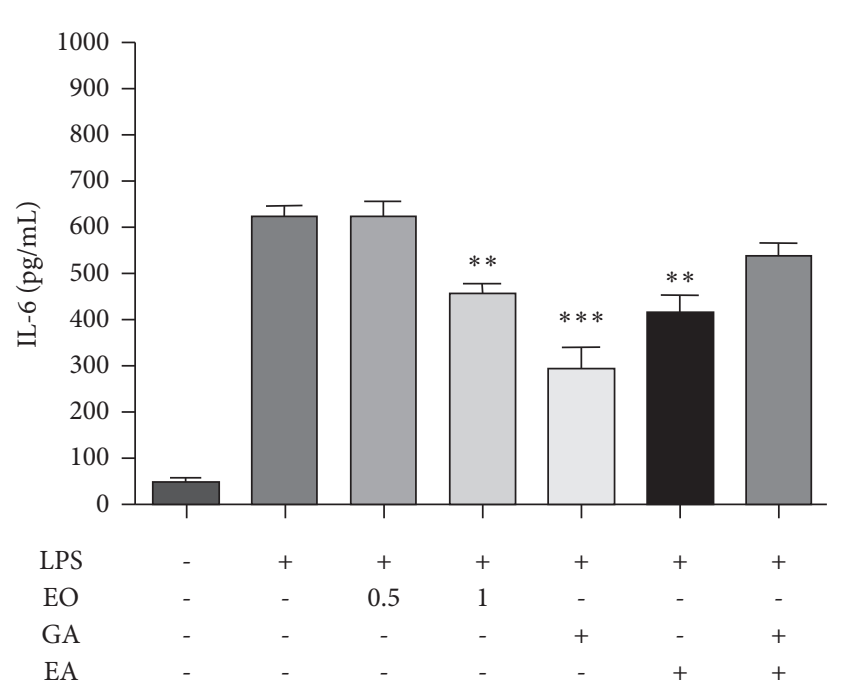

(a)

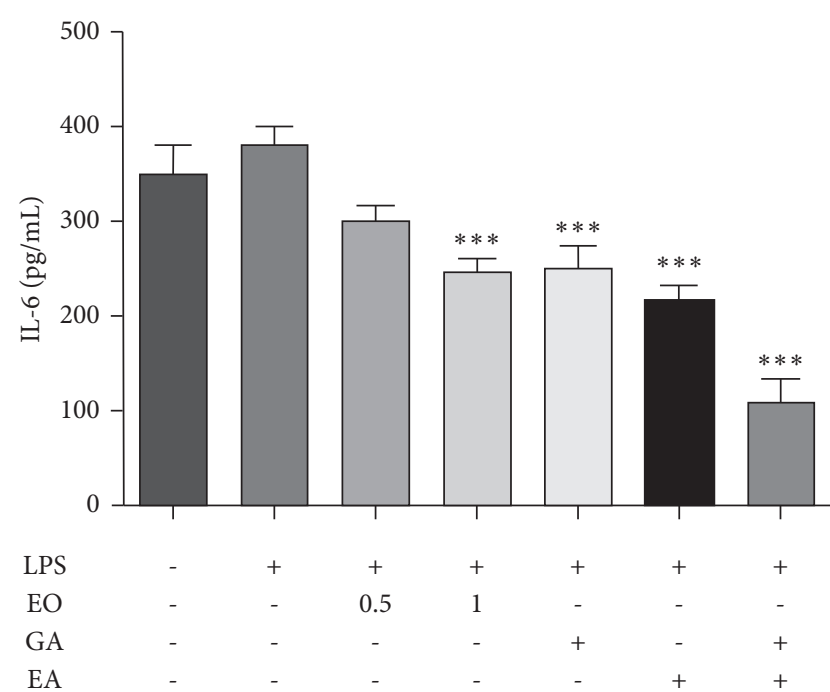

(b)

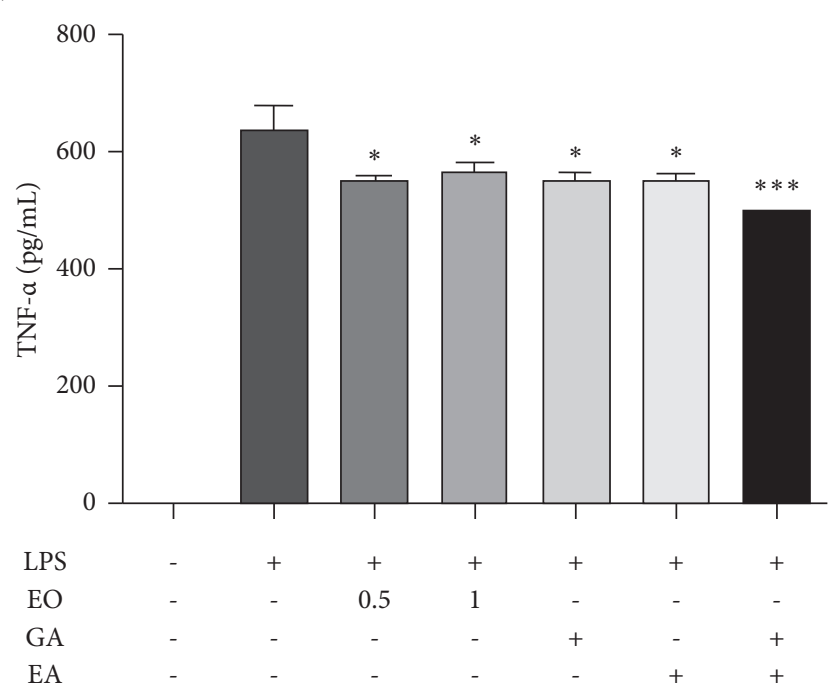

(c)

Figure 3: Effect of EO crude fruit extract on the proinflammatory mediator IL- 6 and TNF- $\alpha$ in BV2 and differentiated Neuro2a cells. Both BV2 and differentiated Neuro2a cells were treated with LPS $(1 \mu \mathrm{g} / \mathrm{mL})$ or EO crude fruit extract $(0.5$ and $1 \mu \mathrm{g} / \mathrm{mL})$. After $24 \mathrm{~h}$, the supernatant was collected, and ELISA assessed the IL- 6 and TNF- $\alpha$ levels. (a) IL-6 level in BV2 cells; (b) IL-6 level in differentiated Neuro2a cells; and (c) TNF- $\alpha$ level in BV2 cells ${ }^{*} p<0.05$. (ANOVA; significant at ${ }^{* *} p<0.01$ and ${ }^{* * *} p<0.001$, compared with the LPS-treated group.)

concentrations of 0.5 and $1 \mu \mathrm{g} / \mathrm{mL}$ tended to decrease the expression level of pERK/ERK by $19.29 \%$ and $11.06 \%$ and that of $\mathrm{pJNK} / \mathrm{JNK}$ by $15.68 \%$ and $24.56 \%$, respectively, compared with the LPS-treated group. Nevertheless, EO crude fruit extract effects on either pERK/ERK or pJNK/ JNK expression did not reach statistical significance (Figure 5). Interestingly, a combined treatment of EA and GA to the LPS-treated cells significantly decreased the expression level of $\mathrm{pJNK} / \mathrm{JNK}$.

3.6. Neurite Outgrowth Stimulatory Effects of EO Crude Fruit Extract on LPS-Treated Differentiated Neuro2a Cells. An earlier study demonstrated that Neuro2a cells expressed TLR4 and LPS administration upregulated inflammatory cytokine expression levels [50]. Therefore, we investigated the direct effect of LPS on neurite length in differentiated Neuro2a cells in this study. Figure 6 presents the morphology of the differentiated Neuro2a cells. LPS affected neither neurite length nor their morphology.

Figures 6 and 7 show that EO crude fruit extract at the concentrations of 0.5 and $1 \mu \mathrm{g} / \mathrm{mL}$ significantly increased the neurite length of LPS-stimulated differentiated Neuro2a cells by $47.08 \%$ and $51.6 \%$, respectively. In addition, GA, EA, and GA + EA treatments significantly induced the neurite length of LPS-treated differentiated Neuro2a cells.

3.7. Effect of EO Crude Fruit Extract on the Expression of TuJ1 and MAP2 Neuronal Markers in LPS-Treated Differentiated Neuro2a Cells. Figure 8 presents the effects of EO crude fruit extract on the mRNA expression of TuJ1 and MAP2 in 

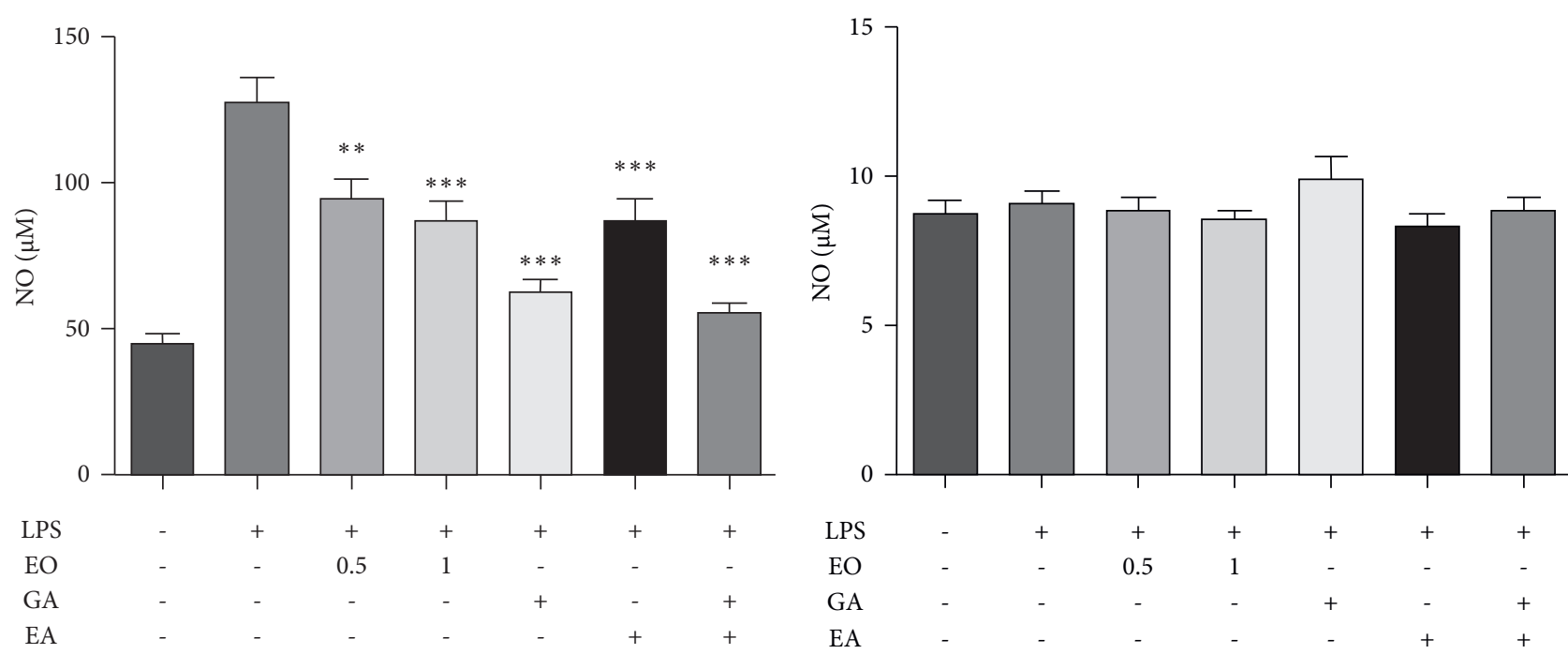

(a)

(b)

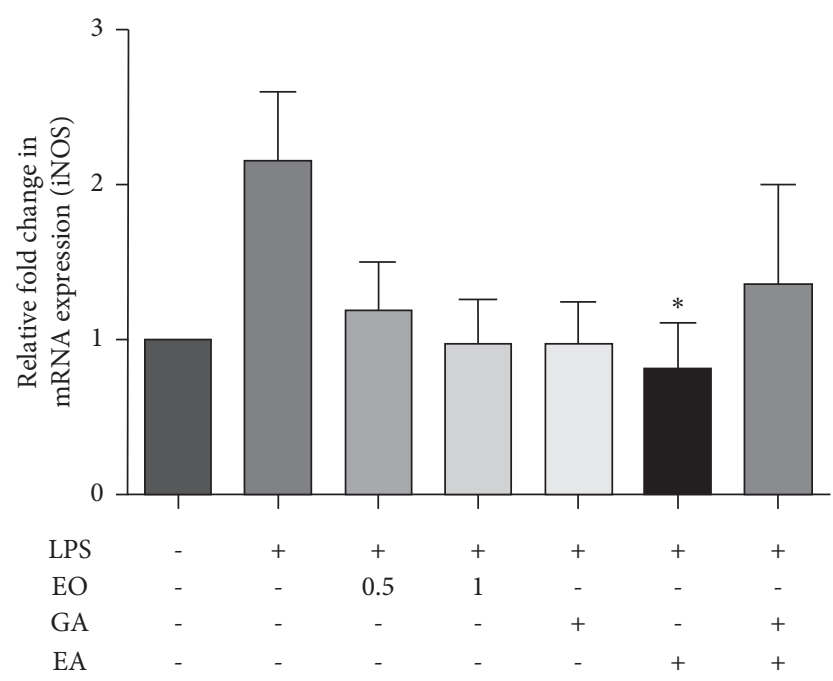

(c)

FIGURE 4: Effect of EO crude fruit extract on NO production and iNOS mRNA expression in BV2 and differentiated Neuro2a cells. Both BV2 and differentiated Neuro2a cells were treated with LPS $(1 \mu \mathrm{g} / \mathrm{mL})$ or EO crude fruit extract $(0.5 \mathrm{or} 1 \mu \mathrm{g} / \mathrm{mL})$. After $24 \mathrm{~h}$, the supernatant was collected, and NO levels were assessed using the Griess assay. Cells were collected to evaluate the iNOS mRNA expression levels. (a) BV2 cells, (b) differentiated Neuro2a cells, and (c) iNOS mRNA expression in BV2 cells were tested by RT-qPCR * $p<0.05$ (ANOVA; significant at ${ }^{* *} p<0.01$ and ${ }^{* * *} p<0.001$, compared with the LPS-treated group.)

Neuro2a cells. In the LPS-treated group, LPS reduced both $\mathrm{TuJ} 1$ and MAP2 mRNA expression levels. Interestingly, EO crude extract at 0.5 and $1 \mu \mathrm{g} / \mathrm{mL}$ increased the TuJ1 mRNA expression level by $205.83 \%$ and $277.60 \%$, respectively, and the MAP2 mRNA expression level by $290.25 \% 216.98 \%$, respectively, compared with the LPS-treated group. However, these changes did not reach statistical significance (Figure 8). Single treatments with either GA or EA significantly induced the mRNA expression of both TuJ1 and MAP2.

Interestingly, cell treatment with $\mathrm{EO}$ crude fruit extract at the concentrations of 0.5 and $1 \mu \mathrm{g} / \mathrm{mL}$ tended to increase the $\mathrm{Tu} 11$ protein expression level by $27.63 \%$ and $18.77 \%$, respectively, compared with the LPS-treated group (Figure 8).

\section{Discussion}

This study evaluated the effect of EO crude fruit extract and its major bioactive compounds against LPS-induced inflammation in both BV2 cells and differentiated Neuro2a cells. The HPLC analysis protocol, modified from Sawant et al. [51], indicated that EO fruit extract contained two major bioactive phenolic compounds, GA and EA. They displayed anti-inflammatory activity by inhibiting LPS-induced NO, PGE-2, and IL-6 production [52]. Thus, they are promising candidates to alleviate various diseases $[53,54]$. EA attenuated the levels of both iNOS and MAPK expression levels induced by LPS in microglia [55]. GA can induce neurite outgrowth in neuroblastoma (SH-SY5Y cells) [56]. In addition, both GA and EA were detectable in 
pERK

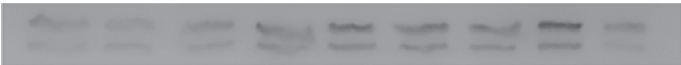

ERK

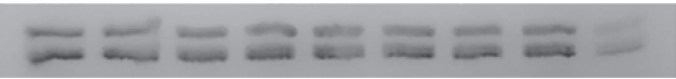

$\beta$-actin
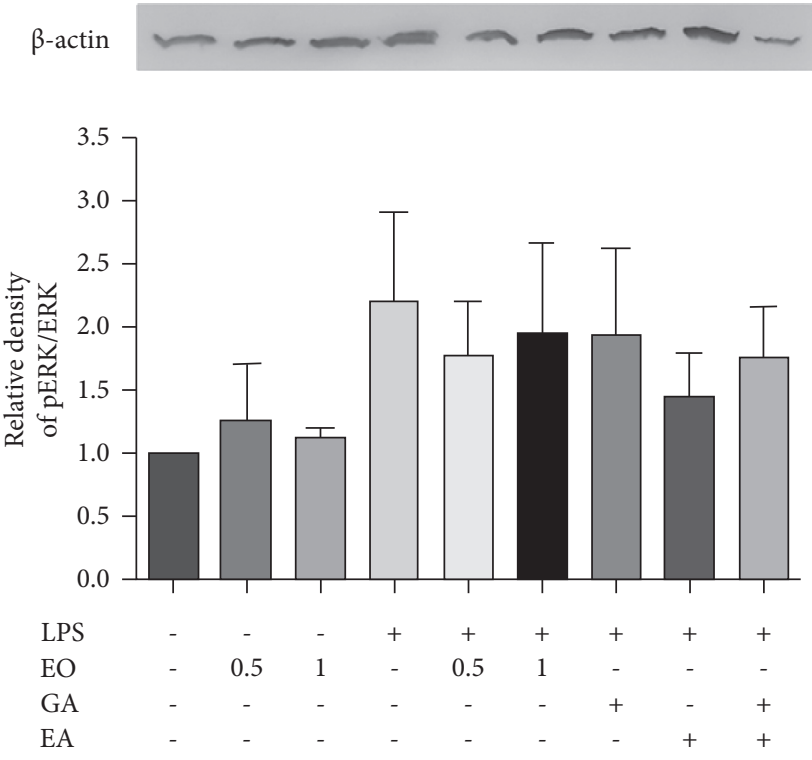

(a)
pJNK

JNK

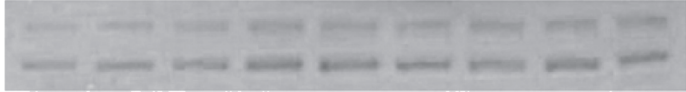

$\beta$-actin
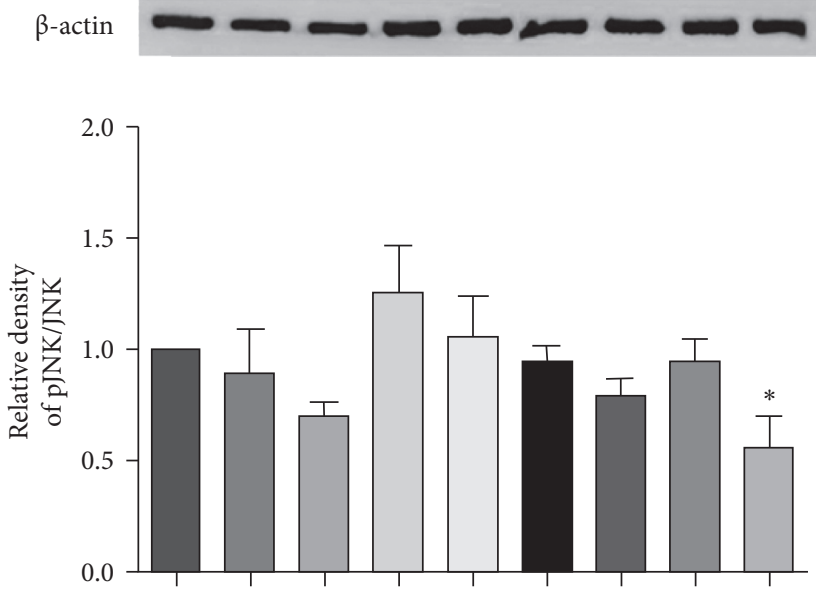

LPS

EO

GA

EA

(b)

FIGURE 5: Effect of EO crude fruit extract on the ERK and JNK pathways in BV2 cells. The cells were treated with LPS ( $1 \mu \mathrm{g} / \mathrm{mL})$ or EO crude fruit extract $(0.5$ or $1 \mu \mathrm{g} / \mathrm{mL})$. After $24 \mathrm{~h}$, cell pellets were collected, and total proteins were extracted. Then, the expression levels of (a) pERK/ ERK, (b) $\mathrm{pJNK} / \mathrm{JNK}$, and $\beta$-actin were assessed by Western blot analysis. All data are presented as mean $\pm \mathrm{SD}$ of three separate experiments. $\left({ }^{*} p<0.05\right.$, compared with the LPS-treated group).

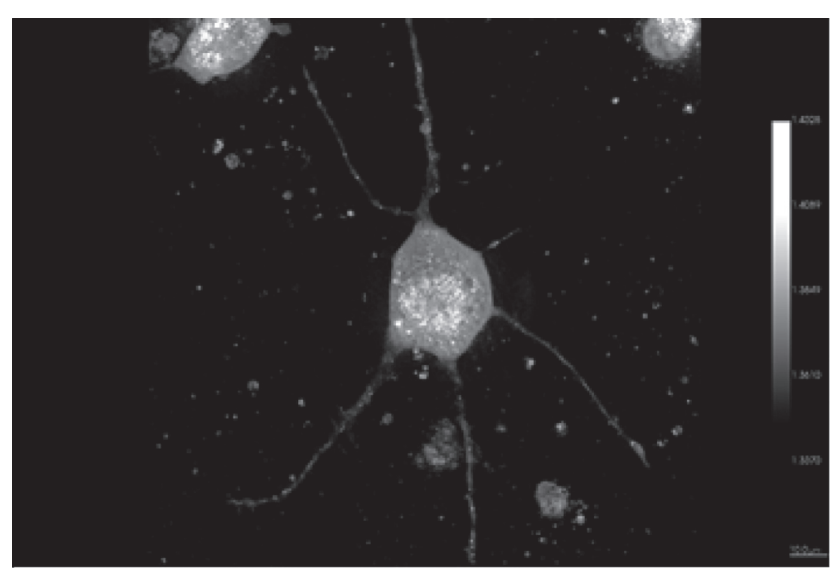

(a)

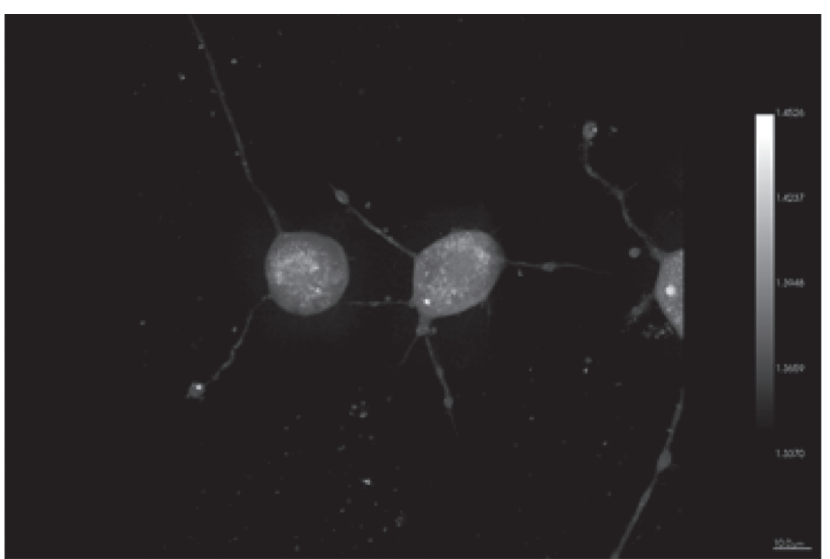

(b)

Figure 6: Continued. 


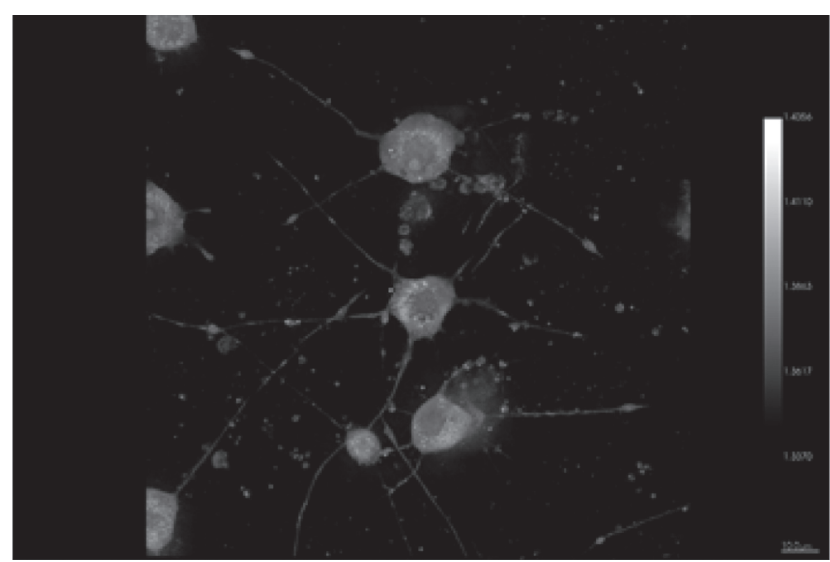

(c)

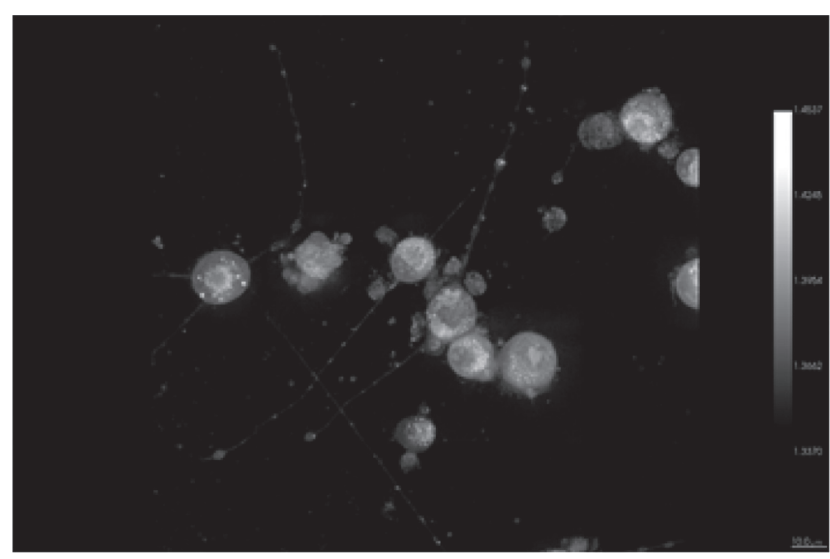

(e)

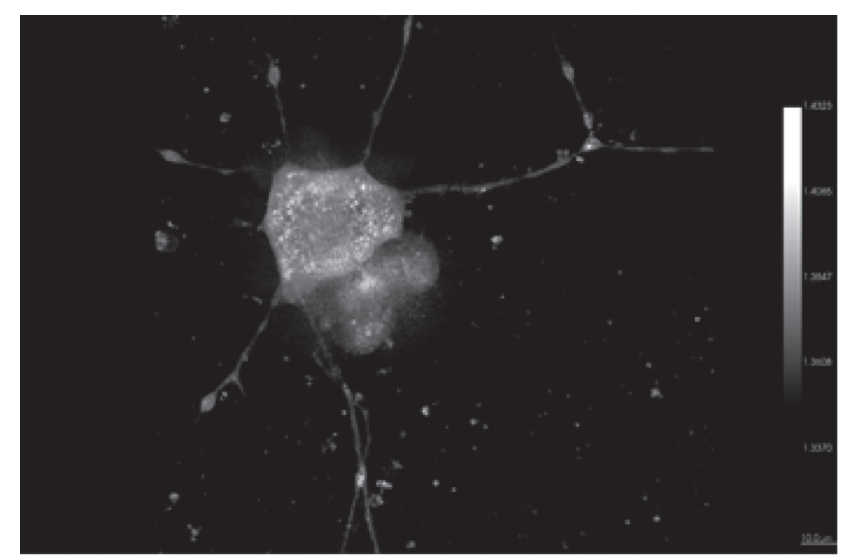

(d)

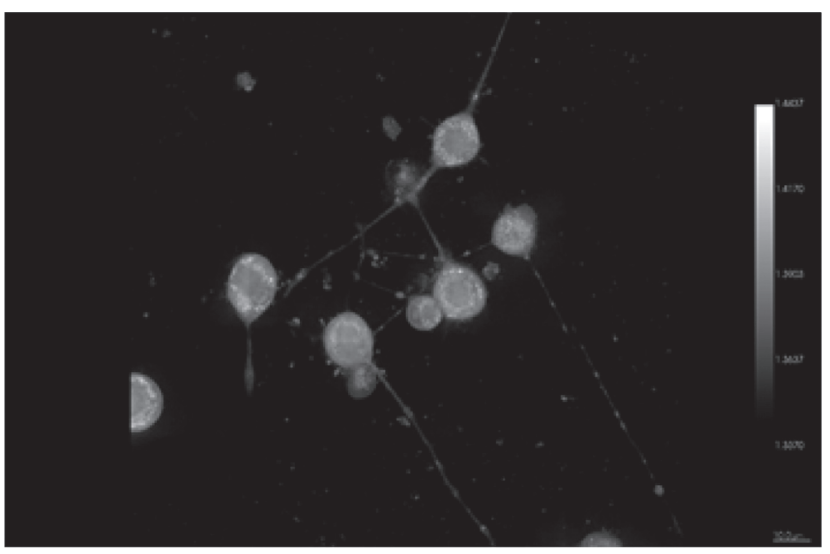

(f)

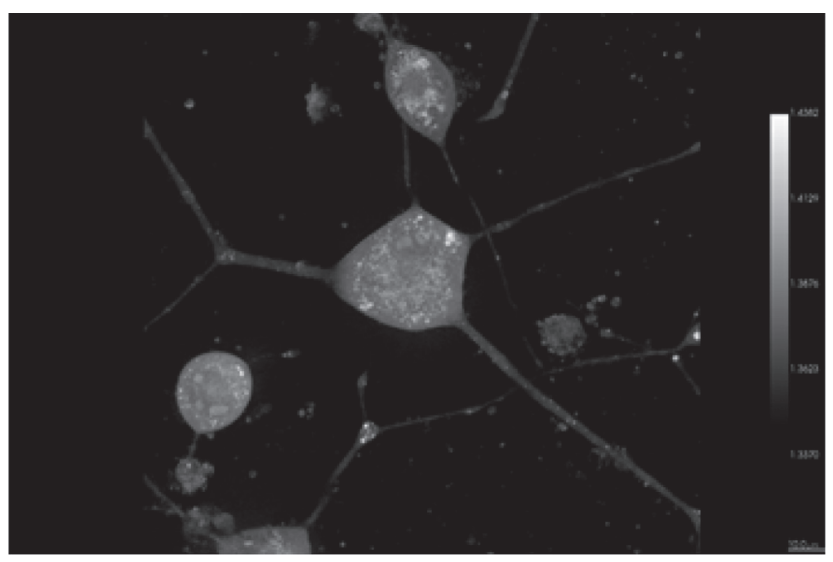

(g)

FIgURE 6: Neurite length of differentiated Neuro2a cells after exposure to EO crude fruit extract, GA, EA, or LPS ( $\times 60$ magnification). (a) Control; (b) LPS; (c) LPS + EO crude fruit extract $0.5 \mu \mathrm{g} / \mathrm{mL}$; (d) LPS + EO crude fruit extract $1 \mu \mathrm{g} / \mathrm{mL}$; (e) LPS + GA; (f) LPS + EA; and (g) LPS + GA + EA.

brain tissues after either oral or intraperitoneal administration, indicating that these substances could pass through the blood-brain barrier $[57,58]$. In animal studies, oral administration of $70 \%$ ethanol EO crude extract showed analgesic effects on postoperative and neuropathic pain in rat models [59]. Acute and chronic toxicity studies did not show any significant toxic side effects $[35,60,61]$.
Interestingly, the combination of EA and GA at the same concentration found in EO crude fruit extract exerted a significantly higher anti-inflammatory effect than the crude extract per se. A variety of phytochemicals present in crude extracts have either antagonistic or synergistic effects. Crude extract has a lower potential than standard treatment, which may be the result of the activity of trace compounds such as alkaloids that are commonly present in the ethanolic extract 


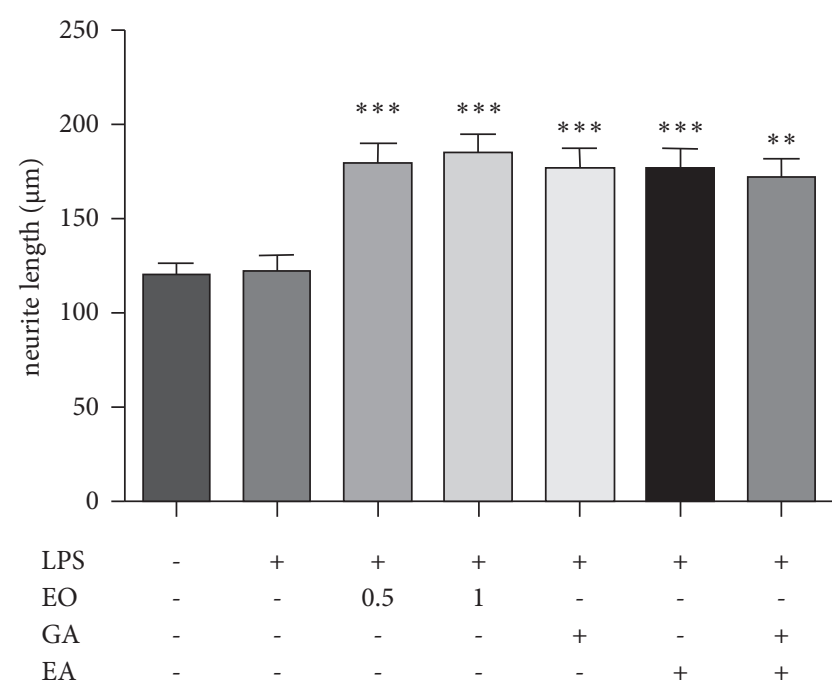

FIgURE 7: Differentiated Neuro2a cells were treated with LPS $(1 \mu \mathrm{g} / \mathrm{mL})$ or EO crude fruit extract $(0.5$ or $1 \mu \mathrm{g} / \mathrm{mL})$ for $24 \mathrm{~h}$. After the treatment, the neurite length was analyzed by MicroCapture v 6.9.10. software (ANOVA; significant at ${ }^{* *} p<0.01$ and *** $p<0.001$, compared with the LPS-treated group).

of EO fruits [62, 63]. Furthermore, alkaloids have display antagonistic effects to phenolic compounds during antioxidant activity [64]. Further studies are needed to explore the bioactivity-guided fractionation of EO extract that possesses anti-inflammatory and neuroprotective activities.

Recently, LPS detection in the human body was associated with several inflammatory-related diseases. An earlier report showed that LPS could be detected in the cerebrospinal fluid $(2.5 \mu \mathrm{g} / \mathrm{L})$ of patients with a meningococcal disease [65]. It induces neuroinflammation as a bridge in neurodegenerative disease models [66]. LPS was also reported to induce microglia activated through the MAPK pathway $[55,67]$ that often precedes neuronal death [14]. In addition, a study dealing with LPS-induced cognitive impairment and neuroinflammation showed the interconnection of microglia activation and neuronal cell loss with increased NO and TNF- $\alpha$ production [15]. Inflammatory neurodegeneration involved activated microglia and overexpression of both iNOS and NO, causing toxicity to neurons $[17,52]$. Our study demonstrates the anti-inflammatory effect of EO crude fruit extract reflected in decreased levels of released NO, IL-6, and TNF- $\alpha$ into the culture media and in downregulation of the expression levels of iNOS mRNA. A recent study also showed anti-inflammatory effects of EO extract in reducing NO, IL-6, and TNF- $\alpha$ levels in macrophages [68]. Moreover, other investigations that involved neuroinflammation demonstrated the effectiveness of both GA and EA to inhibit iNOS protein expression in either glia or neuronal cells [41, 46, 69].

In the $\mathrm{AD}$ brain, amyloid beta can activate microglia through TLR, resulting in increased IL- 6 and NO production [70]. MAPK signaling pathways are implicated in AD development, and persistent activation of JNK signaling pathways might mediate neuronal apoptosis in $\mathrm{AD}$ [71]. The study on phenolic compounds demonstrated that vanillic acid improved memory function by inhibiting the JNK signaling pathway during LPS-induced neurotoxicity in the mouse model [72]. Moreover, a morphology study on human-induced pluripotent stem cells of AD neurons indicated shorter neurites and decreased branching with altered synaptic function [73]. In the present study, EO crude fruit extract significantly decreased IL- 6 , NO, and TNF- $\alpha$ production, partly due to the suppression of both ERK and JNK signaling pathways in LPS-treated BV2 cells. The MAPK pathway regulates many aspects of the proinflammatory cytokine synthesis, including NO, IL-6, and TNF- $\alpha[18,19]$. Suppression of the MAPK pathway reportedly reduced neuroinflammation and neurodegenerative disorders [20, 21]. Moreover, we found that LPS did not significantly affect the activation of ERK and JNK in Neuro2a cells (data not shown).

In the present study, LPS-induced NO, IL-6, and TNF- $\alpha$ production in BV2 cells but did not activate NO and IL- 6 in differentiation Neuro2a cells. These different response patterns to LPS-induced inflammation may result from different specific receptors present on the cell surface. BV2 cells have higher expression levels of IL-6 and TLR4 than Neuro2a cells [74]. Neuroblastoma cells can differently express those receptors. For instance, the SHSY-5Y cell line did not show any TLR4 expression [75]. The NB-1 cell line has been proved to express TLR4 intracellularly but has not responded to LPS due to the lack of interferon regulatory factors [76]. However, the capability of LPS to induce NO production was observed in differentiated Neuro2a cells treated with a high concentration $(12.5 \mu \mathrm{g} / \mathrm{mL})$ of LPS [77]. Our study showed that basal IL-6 levels in differentiated Neuro2a cells were higher than those of BV2 cells, while NO levels were lower. Several neuroblastoma cells are capable of producing IL-6 [78, 79] spontaneously. IL6 has a notorious role in adult neuronal differentiation during the development of new neuronal and glial cells from neural stem cells (NSCs) [16]. Our study showed that EO fruit extract significantly decreased the IL- 6 production in differentiated Neuro2a cells. Consistently, the extract significantly stimulated neurite outgrowth in differentiated Neuro2a cells and potentiated the TuJ1 and MAP2 mRNA expressions and the $\mathrm{TuJ} 1$ protein expression. Both GA and vanillic acid have been shown to possess the ability to promote neurite outgrowth from hippocampal neurons [22]. Neurite outgrowth is crucial for neuronal plasticity, regeneration, and synapticity [80]. The length of neurite outgrowth, which depends on microtubule formation, is the most commonly used parameter in assessing whether studied compounds can affect neurite growth [81]. Histopathological examination of the brain tissue in $\mathrm{AD}$ showed significantly lower neurite outgrowth [82] and dramatically decreased the mature neuronal marker MAP2 expression [83]. Specific drugs used in $\mathrm{AD}$, such as memantine and donepezil, reportedly enhance neurite outgrowth in primary cortical neurons to improve cognitive function [84]. However, the molecular mechanism of EO's stimulatory effect on neurites needs to be elucidated.

We observed two main limitations of this study. First, the experiments were independently performed using only BV2 cells and Neuro2a cells, representing microglia and neuroblastoma cells. However, the effect of EO fruit extract was not investigated in other types of neuronal cells of the CNS, such as 


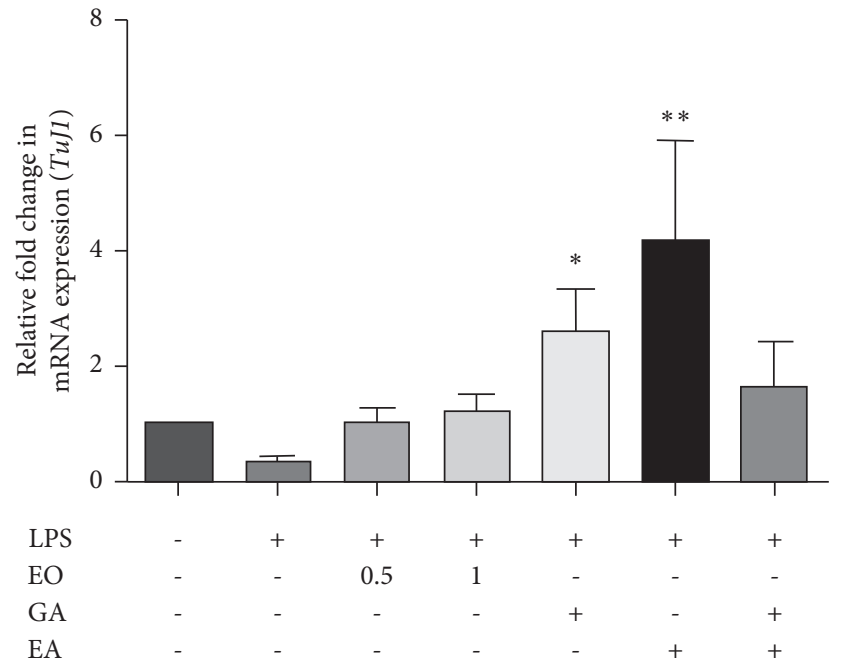

(a)

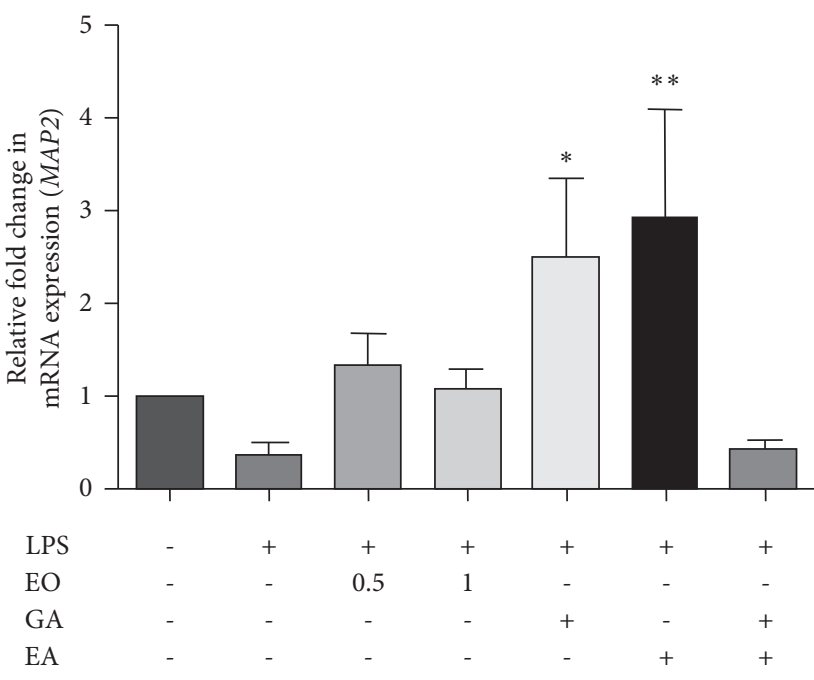

(b)
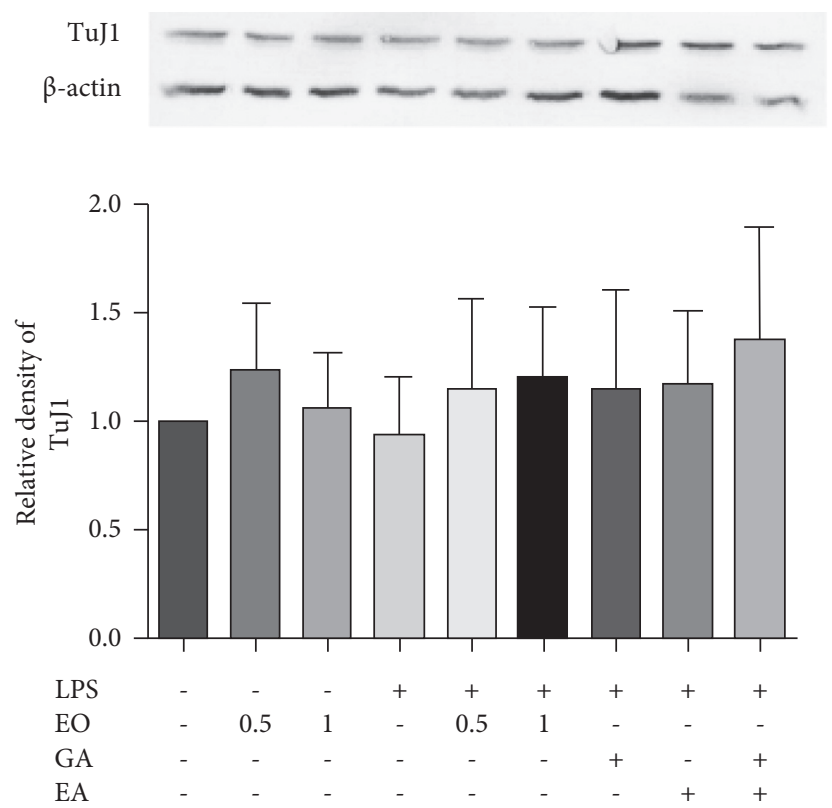

(c)

FiguRE 8: Effect of EO crude extract on the mRNA expression level of two neuronal markers in differentiated Neuro2a cells. Cells were treated with LPS $(1 \mu \mathrm{g} / \mathrm{mL})$ or EO crude fruit extract $(0.5 \mathrm{or} 1 \mu \mathrm{g} / \mathrm{mL})$. After $24 \mathrm{~h}$, the cells were collected, and mRNA expression levels of two neuronal markers ((a) TuJ1 gene and (b) MAP2 gene) were tested by RT-qPCR. (c) TuJ1 protein expression was measured by Western blot. The results are presented as mean $\pm \mathrm{SD} .\left({ }^{*} p<0.05\right.$ and ${ }^{* *} p<0.01$, compared with the LPS-treated group.)

astrocytes and oligodendrocytes. Second, the Neuro2a cell line, being of the neuroblastoma origin, is useful for evaluating only some neuronal properties that may differ in their pharmacological and functional characteristics from neuronal cells [85].

Neuroinflammation stimulated by LPS in BV2 cells caused an increase in IL- $6, \mathrm{NO}$, and TNF- $\alpha$ production. These findings imply that $\mathrm{EO}$ crude fruit extract can ameliorate neuroinflammation in BV2 cells by reducing IL-6, NO, and TNF- $\alpha$ production, possibly via the suppression of ERK and JNK signaling pathways. In addition, EO crude fruit extract was showed to have neuroprotective effects by enhancing neurite outgrowth in Neuro2a cells and may also take part in the upregulation of TuJ1 and MAP2 mRNA expressions as well as TuJ1 protein expression (Figure 9). GA and EA, found in the extract, can serve as anti-inflammatory compounds that exhibit inhibitory effects through the MAPK pathway $[55,86]$. Complementary alternative medicines can improve neuronal function by enhancing neurite outgrowth and reducing microglia activation $[87,88]$. To the best of our knowledge, this is the first report on antineuroinflammation in microglia and neurite outgrowth that are promoted by the activity of ethanolic EO crude fruit extract. It is essential for EO crude fruit extract and its bioactive compounds to be further investigated toward clarifying their potential role in decreasing inflammatory processes and enhancing neurite outgrowth in neuroinflammatory diseases. 


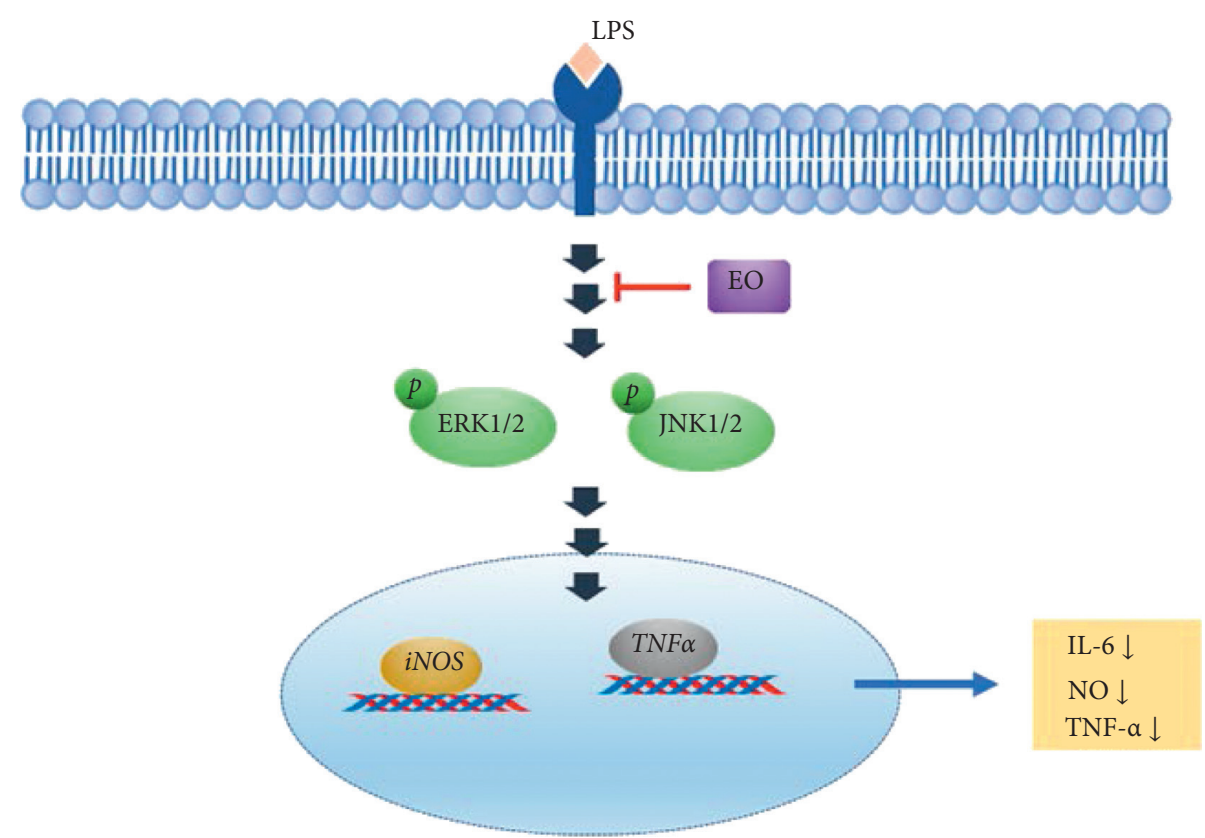

(a)
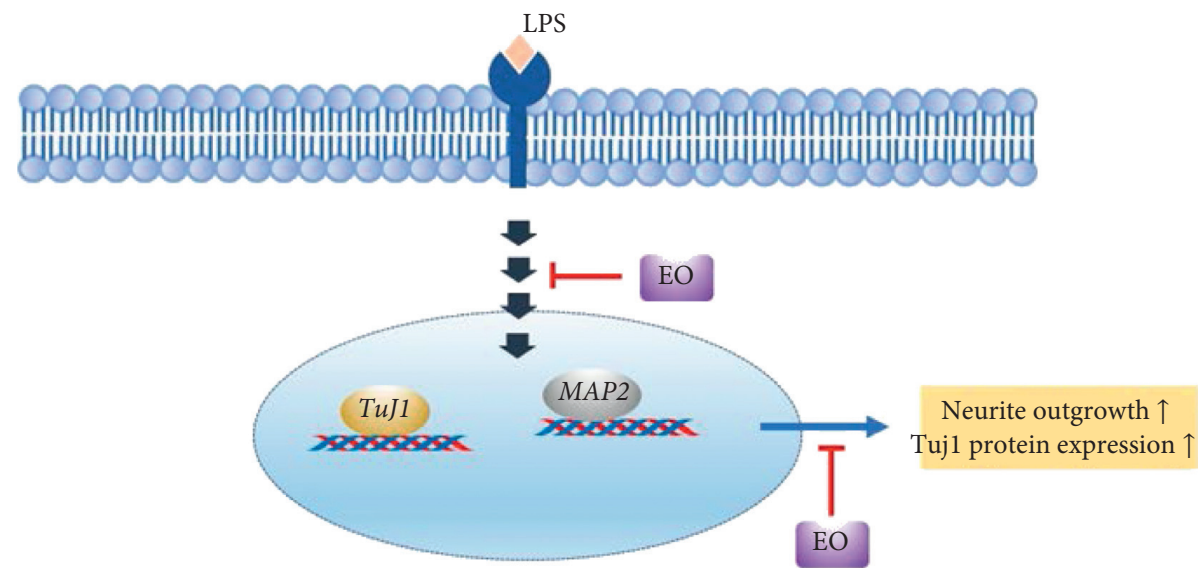

(b)

FIGURE 9: Proposed pathways involved in neuroprotective and anti-inflammatory activities of Emblica officinalis. (a) EO crude fruit extract significantly attenuated proinflammatory cytokine IL-6, NO, and TNF- $\alpha$ in LPS-induced BV2 cells via the ERK1/2 and JNK signaling pathways. (b) Neuroprotective effects are associated with enhanced neurite outgrowth that the TuJ1 and MAP2 mRNA expressions may influence.

\section{Conclusions}

EO crude fruit extract could decrease neuronal inflammation in an LPS-activated model by reducing proinflammatory cytokines released from microglia activation. Our study provides the first evidence that EO fruit extract effectively enhanced neurite length growth by increasing neuronal marker expression and decreasing neuroinflammation in vitro. However, possible underlying mechanisms and molecular targets should be further investigated, contributing to the clinical application of EO crude fruit extract or its derivatives in the therapy of neuroinflammatory diseases. In addition, future studies should fully understand the cellular mechanisms involved in neuroprotection in the coculture model.

\section{Abbreviations}

AD: $\quad$ Alzheimer's disease

ANOVA: Analysis of variance

DMEM: Dulbecco's modified Eagle's medium

EA: $\quad$ Ellagic acid

ELISA: Enzyme-linked immunosorbent assay

ERK: $\quad$ Extracellular signal-regulated kinases

EO: $\quad$ Emblica officinalis

FBS: $\quad$ Fetal bovine serum

GA: $\quad$ Gallic acid

HPLC: High-performance liquid chromatography

JNK: $\quad$ c-Jun N-terminal kinases

IL-6: Interleukin-6

iNOS: Inducible nitric oxide synthase 


$\begin{array}{ll}\text { LPS: } & \text { Lipopolysaccharide } \\ \text { MAP2: } & \text { Microtubule-associated protein } 2 \\ \text { MAPK: } & \text { Mitogen-activated protein kinase } \\ \text { MEM: } & \text { Minimal essential medium } \\ \text { NED: } & \text { N-(1-naphthyl) ethylenediamine } \\ \text { NO: } & \text { Nitric oxide } \\ \text { PD: } & \text { Parkinson's disease } \\ \text { PVDF: } & \text { Polyvinylidene fluoride } \\ \text { RIPA: } & \text { Radioimmunoprecipitation assay } \\ \text { ROS: } & \text { Reactive oxygen species } \\ \text { RPMI: } & \text { Roswell Park Memorial Institute } \\ \text { RT- } & \text { Reverse transcription-quantitative polymerase } \\ \text { qPCR: } & \text { chain reaction } \\ \text { SDS: } & \text { Sodium dodecyl sulfate } \\ \text { TMB: } & \text { Tetramethylbenzidine } \\ \text { TNF- } \alpha: & \text { Tumor necrotic growth factor- } \alpha \\ \text { TLR: } & \text { Toll-like receptor } \\ \text { XTT: } & \text { 2,3-Bis-(2-methoxy-4-nitro-5-sulfophenyl)-2H- } \\ & \text { tetrazolium-5-carboxanilide. }\end{array}$

\section{Data Availability}

All the data used to support the findings of the study are available from the corresponding author upon request.

\section{Conflicts of Interest}

The authors declare that there are no conflicts of interest regarding the publication of this paper.

\section{Authors' Contributions}

BC designed the study and helped coordinate support and funding. BC and DC carried out some experiments and analyzed the data. SP performed all experiments, wrote the manuscript, and interpreted the data. PP and PT performed the statistical analysis and interpreted the data. AC performed Emblica officinalis extraction and HPLC analysis. All the authors participated in the interpretation of the results and the preparation of the manuscript. All the authors read and approved the final manuscript.

\section{Acknowledgments}

This research project was supported by Mahidol University (Grant no. 861139003002).

\section{References}

[1] L. Guzman-Martinez, R. B. Maccioni, V. Andrade, L. P. Navarrete, M. G. Pastor, and N. Ramos-Escobar, "Neuroinflammation as a common feature of neurodegenerative disorders," Frontiers in Pharmacology, vol. 10, no. 1008, 2019.

[2] J. Stephenson, E. Nutma, P. Van Der Valk, and S. Amor, "Inflammation in CNS neurodegenerative diseases," Immunology, vol. 154, no. 2, pp. 204-219, 2018.

[3] N. T. Sprenkle, S. G. Sims, C. L. Sánchez, and G. P. Meares, "Endoplasmic reticulum stress and inflammation in the central nervous system," Molecular Neurodegeneration, vol. 12, no. 1, p. 42, 2017.

[4] V. H. Perry and J. Teeling, "Microglia and macrophages of the central nervous system: the contribution of microglia priming and systemic inflammation to chronic neurodegeneration," Seminars in Immunopathology, vol. 35, no. 5, pp. 601-612, 2013.

[5] M. E. Lull and M. L. Block, "Microglial activation and chronic neurodegeneration," Neurotherapeutics, vol. 7, no. 4, pp. 354-365, 2010.

[6] S. Petratos, Q.-X. Li, A. J. George et al., "The $\beta$-amyloid protein of Alzheimer's disease increases neuronal CRMP-2 phosphorylation by a Rho-GTP mechanism," Brain, vol. 131, no. 1, pp. 90-108, 2008.

[7] S. Hickman, S. Izzy, P. Sen, L. Morsett, and J. El Khoury, "Microglia in neurodegeneration," Nature Neuroscience, vol. 21, no. 10, pp. 1359-1369, 2018.

[8] S. Lively and L. C. Schlichter, "Microglia responses to proinflammatory stimuli (LPS, IFN $\gamma+\mathrm{TNF} \alpha$ ) and reprogramming by resolving cytokines (IL-4, IL-10)," Frontiers in Cellular Neuroscience, vol. 12, no. 215, 2018.

[9] J. A. Martínez-Díaz, M. E. Hernández-Aguilar, F. RojasDurán et al., "Expression of proteins linked to Alzheimer's disease in C6 rat glioma cells under the action of lipopolysaccharide (LPS), nimesulide, resveratrol and citalopram," Turkish Journal of Biochemistry, vol. 45, no. 6, pp. 793-801, 2020.

[10] Y. F. Zheng, X. Zhou, D. Chang et al., "A novel tri-culture model for neuroinflammation," Journal of Neurochemistry, vol. 156, no. 2, pp. 249-261, 2020.

[11] B.-K. Park, Y. H. Kim, Y. R. Kim et al., "Antineuroinflammatory and neuroprotective effects of gyejibokryeong-hwan in lipopolysaccharide-stimulated BV2 microglia," Evidence-based Complementary and Alternative Medicine, vol. 2019, Article ID 7585896, 14 pages, 2019.

[12] A. D. Kraft and G. J. Harry, "Features of microglia and neuroinflammation relevant to environmental exposure and neurotoxicity," International Journal of Environmental Research and Public Health, vol. 8, no. 7, pp. 2980-3018, 2011.

[13] T. H. Mogensen, "Pathogen recognition and inflammatory signaling in innate immune defenses," Clinical Microbiology Reviews, vol. 22, no. 2, pp. 240-273, 2009.

[14] L. Minghetti, M. A. Ajmone-Cat, M. A. De Berardinis, and R. De Simone, "Microglial activation in chronic neurodegenerative diseases: roles of apoptotic neurons and chronic stimulation," Brain Research Reviews, vol. 48, no. 2, pp. 251-256, 2005.

[15] J. Zhao, W. Bi, S. Xiao et al., "Neuroinflammation induced by lipopolysaccharide causes cognitive impairment in mice," Scientific Reports, vol. 9, no. 1, p. 5790, 2019.

[16] M. Erta, A. Quintana, and J. Hidalgo, "Interleukin-6, a major cytokine in the central nervous system," International Journal of Biological Sciences, vol. 8, no. 9, pp. 1254-1266, 2012.

[17] U. Förstermann and W. C. Sessa, "Nitric oxide synthases: regulation and function," European Heart Journal, vol. 33, no. 7, pp. 829-837, 2012.

[18] K. K. Nyati, K. Masuda, M. M.-U. Zaman et al., "TLR4-induced NF- $\kappa$ B and MAPK signaling regulate the IL- 6 mRNA stabilizing protein Arid5a," Nucleic Acids Research, vol. 45, no. 5, pp. 2687-2703, 2017.

[19] M.-J. Kim, S.-J. Kim, S. S. Kim, N. H. Lee, and C.-G. Hyun, "Hypochoeris radicata attenuates LPS-induced inflammation by suppressing p38, ERK, and JNK phosphorylation in RAW 264.7 macrophages," EXCLI Journal, vol. 13, 2014. 
[20] J. Sun and G. Nan, “The extracellular signal-regulated kinase $1 / 2$ pathway in neurological diseases: a potential therapeutic target (Review)," International Journal of Molecular Medicine, vol. 39, no. 6, pp. 1338-1346, 2017.

[21] H.-S. Lim, Y. J. Kim, B.-Y. Kim, and S.-J. Jeong, "Bakuchiol suppresses inflammatory responses via the downregulation of the p38 MAPK/ERK signaling pathway," International Journal of Molecular Sciences, vol. 20, no. 14, p. 3574, 2019.

[22] S. Siddiqui, A. Kamal, F. Khan, K. S. Jamali, and Z. S. Saify, "Gallic and vanillic acid suppress inflammation and promote myelination in an in vitro mouse model of neurodegeneration," Molecular Biology Reports, vol. 46, no. 1, pp. 997-1011, 2019.

[23] S. Lee, K. Choi, H. Ahn, K. Song, J. Choe, and I. Lee, "TuJ1 (class III $\beta$-tubulin) expression suggests dynamic redistribution of follicular dendritic cells in lymphoid tissue," $E \mathbf{E}$ ropean Journal of Cell Biology, vol. 84, no. 2-3, pp. 453-459, 2005.

[24] S. Y. Chun, S. Soker, Y.-J. Jang, T. G. Kwon, and E. S. Yoo, "Differentiation of human dental pulp stem cells into dopaminergic neuron-like cells in vitro," Journal of Korean Medical Science, vol. 31, no. 2, pp. 171-177, 2016.

[25] D. E. Korzhevskii, M. N. Karpenko, and O. V. Kirik, "Microtubule-associated proteins as indicators of differentiation and the functional state of nerve cells," Neuroscience and Behavioral Physiology, vol. 42, no. 3, pp. 215-222, 2012.

[26] W. B. Jeon, B. H. Park, S. K. Choi, K.-M. Lee, and J.-K. Park, "Functional enhancement of neuronal cell behaviors and differentiation by elastin-mimetic recombinant protein presenting Arg-Gly-Asp peptides," BMC Biotechnology, vol. 12, no. 1, p. 61, 2012.

[27] L. Dehmelt, F. M. Smart, R. S. Ozer, and S. Halpain, "The role of microtubule-associated protein $2 \mathrm{c}$ in the reorganization of microtubules and lamellipodia during neurite initiation," Journal of Neuroscience, vol. 23, no. 29, pp. 9479-9490, 2003.

[28] K. Pemberton, B. Mersman, and F. Xu, "Using ImageJ to assess neurite outgrowth in mammalian cell cultures: research data quantification exercises in undergraduate neuroscience lab," Journal of Undergraduate Neuroscience Education: June: a publication of Fun, Faculty for Undergraduate Neuroscience, vol. 16, no. 2, pp. A186-A94, 2018.

[29] W. Yu, H. K. Lee, S. Hariharan, W. Bu, and S. Ahmed, "Quantitative neurite outgrowth measurement based on image segmentation with topological dependence," Cytometry, Part A, vol. 75A, no. 4, pp. 289-297, 2009.

[30] N. Limpeanchob, S. Jaipan, S. Rattanakaruna, W. Phrompittayarat, and K. Ingkaninan, "Neuroprotective effect of Bacopa monnieri on beta-amyloid-induced cell death in primary cortical culture," Journal of Ethnopharmacology, vol. 120, no. 1, pp. 112-117, 2008.

[31] S. N. Rai, H. Birla, S. S. Singh et al., "Mucuna pruriens protects against MPTP intoxicated neuroinflammation in Parkinson's disease through NF- $\kappa \mathrm{B} / \mathrm{pAKT}$ signaling pathways," Frontiers in Aging Neuroscience, vol. 9, no. 421, 2017.

[32] M. S. Baliga, A. R. Shivashankara, K. R. Thilakchand et al., "Hepatoprotective effects of the Indian gooseberry (emblica officinalis gaertn)," in Dietary Interventions in Liver Disease, R. R. Watson and V. R. Preedy, Eds., Academic Press, Cambridge, MA, USA, pp. 193-201, 2019.

[33] A. Wongnoppavich, J. Kanjana, and S. Seewaboon, "Triphala: the Thai traditional herbal formulation for cancer treatment," Songklanakarin Journal of Science and Technology, vol. 31, 2009.
[34] B. Sripanidkulchai and N. Fangkrathok, "Antioxidant, antimutagenic and antibacterial activities of extracts from Phyllanthus emblica branches," Songklanakarin Journal of Science and Technology, vol. 36, pp. 669-674, 2014.

[35] T. Usha, S. Middha, A. Goyal et al., "Toxicological evaluation of emblica officinalis fruit extract and its anti-inflammatory and free radical scavenging properties," Pharmacognosy Magazine, vol. 11, no. 44, pp. 427-S33, 2015.

[36] R. Chaphalkar, K. G. Apte, Y. Talekar, S. K. Ojha, and M. Nandave, "Antioxidants ofPhyllanthus emblicaL. Bark extract provide hepatoprotection against ethanol-induced hepatic damage: a comparison with silymarin," Oxidative medicine and cellular longevity, vol. 2017, Article ID 3876040, 10 pages, 2017.

[37] A. Tasanarong, S. Kongkham, and A. Itharat, "Antioxidant effect of Phyllanthus emblica extract prevents contrast-induced acute kidney injury," BMC Complementary and Alternative Medicine, vol. 14, no. 1, p. 138, 2014.

[38] P. Bhandari and M. Kamdod, "Emblica officinalis (Amla): a review of potential therapeutic applications," International Journal of Green Pharmacy, vol. 6, no. 4, p. 257, 2012.

[39] W. Luo, M. Zhao, B. Yang, G. Shen, and G. Rao, "Identification of bioactive compounds in Phyllenthus emblica L. fruit and their free radical scavenging activities," Food Chemistry, vol. 114, no. 2, pp. 499-504, 2009.

[40] P. I. Schimites, H. J. Segat, L. G. Teixeira et al., "Gallic acid prevents ketamine-induced oxidative damages in brain regions and liver of rats," Neuroscience Letters, vol. 714, Article ID 134560, 2020.

[41] Y.-L. Liu, C.-C. Hsu, H.-J. Huang, C.-J. Chang, S.-H. Sun, and A. M.-Y. Lin, "Gallic acid attenuated LPS-induced neuroinflammation: protein aggregation and necroptosis," Molecular Neurobiology, vol. 57, no. 1, pp. 96-104, 2020.

[42] S. Rakshit, S. K. Nirala, and M. Bhadauria, "Gallic acid protects from acute multiorgan injury induced by lipopolysaccharide and D-galactosamine," Current Pharmaceutical Biotechnology, vol. 21, no. 14, pp. 1489-1504, 2020.

[43] M. A. Mirshekar, A. Sarkaki, Y. Farbood et al., "Neuroprotective effects of gallic acid in a rat model of traumatic brain injury: behavioral, electrophysiological, and molecular studies," Iranian Journal of Basic Medical Sciences, vol. 21, no. 10, pp. 1056-1063, 2018.

[44] K. Hassonizadeh Falahieh, A. Sarkaki, M. Edalatmanesh, M. K. Gharib Naseri, and Y. Farbood, "Ellagic acid attenuates post-cerebral ischemia and reperfusion behavioral deficits by decreasing brain tissue inflammation in rats," Iranian Journal of Basic Medical Sciences, vol. 23, no. 5, pp. 645-653, 2020.

[45] A. Aslan, O. Gok, S. Beyaz, E. Arslan, O. Erman, and C. A. Ağca, "The preventive effect of ellagic acid on brain damage in rats via regulating of Nrf-2, NF- $k \mathrm{~B}$ and apoptotic pathway," Journal of Food Biochemistry, vol. 44, no. 6, Article ID e13217, 2020.

[46] G. L. Dornelles, J. S. De Oliveira, E. J. R. De Almeida et al., "Ellagic acid inhibits neuroinflammation and cognitive impairment induced by lipopolysaccharides," Neurochemical Research, vol. 45, no. 10, pp. 2456-2473, 2020.

[47] S. Shimizu, M. Kondo, Y. Miyamoto, and M. Hayashi, "Foxa(HNF3) up-regulates vitronectin expression during retinoic acid-induced differentiation in mouse neuroblastoma Neuro2a cells," Cell Structure and Function, vol. 27, no. 4, pp. 181-188, 2002.

[48] A. Namsi, T. Nury, H. Hamdouni et al., "Induction of neuronal differentiation of murine N2a cells by two polyphenols present in the mediterranean diet mimicking neurotrophins 
activities: resveratrol and apigenin,” Diseases, vol. 6, no. 3, p. 67, 2018.

[49] M. Kumar and A. Katyal, "Data on retinoic acid and reduced serum concentration induced differentiation of Neuro-2a neuroblastoma cells," Data in Brief, vol. 21, pp. 2435-2440, 2018.

[50] C. Yang, R.-Y. Jiang, J. Shen et al., "Ketamine attenuates the lipopolysaccharide-induced inflammatory response in cultured N2a cells," Molecular Medicine Reports, vol. 8, no. 1, pp. 217-220, 2013.

[51] L. Sawant, B. Prabhakar, and N. Pandita, Quantitative HPLC Analysis of Ascorbic Acid and Gallic Acid in Phyllanthus Emblica, 2010.

[52] L. A. BenSaad, K. H. Kim, C. C. Quah, W. R. Kim, and M. Shahimi, "Anti-inflammatory potential of ellagic acid, gallic acid and punicalagin A\&B isolated from Punica granatum," BMC Complementary and Alternative Medicine, vol. 17, no. 1, p. 47, 2017.

[53] N. Kahkeshani, F. Farzaei, M. Fotouhi et al., "Pharmacological effects of gallic acid in health and diseases: a mechanistic review," Iranian journal of basic medical sciences, vol. 22, no. 3, pp. 225-237, 2019.

[54] J.-L. Ríos, R. Giner, M. Marín, and M. Recio, "A pharmacological update of ellagic acid," Planta Medica, vol. 84, no. 15, pp. 1068-1093, 2018.

[55] E. N. Ismail, N. Azmi, and I. Jantan, "Ellagic acid protects against activation of microglia by inhibiting MAPKs and NF$\kappa \mathrm{B}$ signalling," Indian Journal of Pharmaceutical Education and Research, vol. 54, no. 3s, pp. s529-s536, 2020.

[56] M. Pervin, K. Unno, T. Ohishi, H. Tanabe, N. Miyoshi, and Y. Nakamura, "Beneficial effects of green tea catechins on neurodegenerative diseases," Molecules, vol. 23, no. 6, p. 1297, 2018.

[57] R. W. Teel, "Distribution and metabolism of ellagic acid in the mouse following intraperitoneal administration," Cancer Letters, vol. 34, no. 2, pp. 165-171, 1987.

[58] L. Yan, P. Yin, C. Ma, and Y. Liu, "Method development and validation for pharmacokinetic and tissue distributions of ellagic acid using ultrahigh performance liquid chromatography-tandem mass spectrometry (UPLC-MS/MS)," Molecules, vol. 19, no. 11, pp. 18923-18935, 2014.

[59] D. Lim, J. Kim, and Y. Kim, "Analgesic effect of Indian gooseberry (emblica officinalis fruit) extracts on postoperative and neuropathic pain in rats," Nutrients, vol. 8 , no. 12 , p. 760 , 2016.

[60] G. Pandey and S. P. Pandey, "Phytochemical and toxicity study of Emblica officinalis (Amla)," International Research Journal of Pharmacy, vol. 2, pp. 270-272, 2011.

[61] M. P. Kapoor, K. Suzuki, T. Derek, M. Ozeki, and T. Okubo, "Clinical evaluation of Emblica Officinalis Gatertn (Amla) in healthy human subjects: health benefits and safety results from a randomized, double-blind, crossover placebo-controlled study," Contemporary clinical trials communications, vol. 17, Article ID 100499, 2020.

[62] N. Kadhim, D. Aziz, and M. Hadi, "HPLC fractioning to study the synergy and antagonism of rue plant seeds alkaloid to inhibit topoisomerase II as antitumor," American Journal of BioMedicine, vol. 4, no. 7, pp. 253-262, 2016.

[63] T. Milanda, A. S. W. Kusuma, and K. Shanmuganathan, "Antibacterial activity of malacca fruit (phyllantus emblica L.) ethanolic extract and fractionagainstbacillus cereus FNCC0057 andshigella dysenteriae ATCC13313," Asian Journal of Pharmaceutical and Clinical Research, vol. 10, no. 14, p. $8,2017$.
[64] X. Sun, D. Zhang, L. Zhao et al., “Antagonistic interaction of phenols and alkaloids in Sichuan pepper (Zanthoxylum bungeanum) pericarp," Industrial Crops and Products, vol. 152, Article ID 112551, 2020.

[65] P. Brandtzaeg, R. Ovstebo, P. Kierulf, and P. Kierulf, "Compartmentalization of lipopolysaccharide production correlates with clinical presentation in meningococcal disease," Journal of Infectious Diseases, vol. 166, no. 3, pp. 650-652, 1992.

[66] S. Bachiller, I. Jiménez-Ferrer, A. Paulus et al., "Microglia in neurological diseases: a road map to brain-disease dependentinflammatory response," Frontiers in Cellular Neuroscience, vol. 12, no. 488, 2018.

[67] B. Xing, A. D. Bachstetter, and L. J. Van Eldik, "Microglial p38 $\alpha$ MAPK is critical for LPS-induced neuron degeneration, through a mechanism involving TNF $\alpha$," Molecular Neurodegeneration, vol. 6, no. 1, p. 84, 2011.

[68] W. Li, H. W. Zhu, Y. J. Chen et al., "Bioactivity-guided isolation of anti-inflammatory components from Phyllanthus emblica," Food Sciences and Nutrition, vol. 8, no. 6, pp. 2670-2679, 2020.

[69] M. T. Ardah, G. Bharathan, T. Kitada, and M. E. Haque, "Ellagic acid prevents dopamine neuron degeneration from oxidative stress and neuroinflammation in MPTP model of Parkinson's disease," Biomolecules, vol. 10, no. 11, p. 1519, 2020.

[70] W. Y. Wang, M. S. Tan, J. T. Yu, and L. Tan, "Role of proinflammatory cytokines released from microglia in Alzheimer's disease," Annals of Translational Medicine, vol. 3, no. 10, p. 136, 2015.

[71] E. K. Kim and E.-J. Choi, "Pathological roles of MAPK signaling pathways in human diseases," Biochimica et Biophysica Acta-Molecular Basis of Disease, vol. 1802, no. 4, pp. 396-405, 2010.

[72] R. Ullah, M. Ikram, T. J. Park et al., "Vanillic acid, a bioactive phenolic compound, counteracts LPS-induced neurotoxicity by regulating c-jun $\mathrm{N}$-terminal kinase in mouse brain," International Journal of Molecular Sciences, vol. 22, no. 1, p. 361, 2020.

[73] S. Ghatak, N. Dolatabadi, D. Trudler et al., "Mechanisms of hyperexcitability in Alzheimer's disease hiPSC-derived neurons and cerebral organoids vs isogenic controls," eLife, vol. 8, Article ID e50333, 2019.

[74] M. D. Burton, N. L. Sparkman, and R. W. Johnson, "Inhibition of interleukin- 6 trans-signaling in the brain facilitates recovery from lipopolysaccharide-induced sickness behavior," Journal of Neuroinflammation, vol. 8, no. 1, p. 54, 2011.

[75] M. Molteni, D. Marabella, C. Orlandi, and C. Rossetti, "Melanoma cell lines are responsive in vitro to lipopolysaccharide and express TLR-4," Cancer Letters, vol. 235, no. 1, pp. 75-83, 2006.

[76] F. Hassan, S. Islam, G. Tumurkhuu et al., "Intracellular expression of toll-like receptor 4 in neuroblastoma cells and their unresponsiveness to lipopolysaccharide," BMC Cancer, vol. 6, no. 1, p. 281, 2006.

[77] N. Steiner, R. Balez, N. Karunaweera, J. M. Lind, G. Münch, and L. Ooi, "Neuroprotection of Neuro2a cells and the cytokine suppressive and anti-inflammatory mode of action of resveratrol in activated RAW264.7 macrophages and C8-B4 microglia," Neurochemistry International, vol. 95, pp. 46-54, 2016.

[78] Q. Bin, B. D. Johnson, D. W. Schauer, J. T. Casper, and R. J. Orentas, "Production of macrophage migration 
inhibitory factor by human and murine neuroblastoma," Tumor Biology, vol. 23, no. 3, pp. 123-129, 2002.

[79] R. A. Egler, S. M. Burlingame, J. G. Nuchtern, and H. V. Russell, "Interleukin-6 and soluble interleukin-6 receptor levels as markers of disease extent and prognosis in neuroblastoma," Clinical Cancer Research, vol. 14, no. 21, pp. 7028-7034, 2008.

[80] R. Salto, J. D. Vílchez, M. D. Girón et al., " $\beta$-Hydroxy$\beta$-Methylbutyrate (HMB) promotes neurite outgrowth in Neuro2a cells," PloS One, vol. 10, no. 8, Article ID e0135614, 2015.

[81] N. Tangsaengvit, W. Kitphati, S. Tadtong, N. Bunyapraphatsara, and V. Nukoolkarn, "Neurite outgrowth and neuroprotective effects of quercetin fromCaesalpinia mimosoidesLamk. On cultured P19-derived neurons," Evidence-based Complementary and Alternative Medicine, vol. 2013, Article ID 838051, 7 pages, 2013.

[82] M. Tolar, S. A. Scott, and K. A. Crutcher, "Sympathetic neurite outgrowth is greater on plaque-poor vs. plaque-rich regions of Alzheimer's disease cryostat sections," Brain Research, vol. 787, no. 1, pp. 49-58, 1998.

[83] B. Li, H. Yamamori, Y. Tatebayashi et al., "Failure of neuronal maturation in Alzheimer disease dentate gyrus," Journal of Neuropathology \& Experimental Neurology, vol. 67, no. 1, pp. 78-84, 2008.

[84] M. Page, N. Pacico, S. Ourtioualous, T. Deprez, and K. Koshibu, "Procognitive compounds promote neurite outgrowth," Pharmacology, vol. 96, no. 3-4, pp. 131-136, 2015.

[85] K. T. LePage, R. W. Dickey, W. H. Gerwick, E. L. Jester, and T. F. Murray, "On the use of neuro-2a neuroblastoma cells versus intact neurons in primary culture for neurotoxicity studies," Critical Reviews in Neurobiology, vol. 17, no. 1, pp. 27-50, 2005.

[86] C.-Z. Liang, X. Zhang, H. Li et al., "Gallic acid induces the apoptosis of human osteosarcoma cells in vitro and in vivo via the regulation of mitogen-activated protein kinase pathways," Cancer Biotherapy and Radiopharmaceuticals, vol. 27, no. 10, pp. 701-710, 2012.

[87] M.-K. Chen, C.-C. Peng, R. S. Maner, N. D. Zulkefli, S.-M. Huang, and C.-L. Hsieh, "Geniposide ameliorated fluoxetine-suppressed neurite outgrowth in Neuro2a neuroblastoma cells," Life Sciences, vol. 226, pp. 1-11, 2019.

[88] E. N. Ismail, I. Jantan, S. Vidyadaran, J. A. Jamal, and N. Azmi, "Phyllanthus amarus prevents LPS-mediated BV2 microglial activation via MyD88 and NF- $\kappa \mathrm{B}$ signaling pathways," BMC Complementary Medicine and Therapies, vol. 20, no. 1, p. 202, 2020. 